\title{
Effect of Dispersion Method for Nano-Materials on Some Mechanical Properties of Cement Mortar
}

\author{
Mohammed J. Kadhim, Hamza M. Kamal \\ Department of Materials Engineering, College of Engineering, Al-Mustansiriyah University
}

\begin{abstract}
This study was involving the dispersion method of nano-materials replacement and the interaction with cement mortar behavior for many mortar samples under variable curing time, with constant water to cement ratio $(\mathrm{W} / \mathrm{C}=0.45)$.Some mechanical properties such as (compressive, flexural strength and hardness tests) was studied. The main parameters are depending on the small amount replacement ratio of nano-particle $\left(\mathrm{ZrO}_{2}\right)$ with respect to the mass of the cement (OPC) type (I). The addition of nano-material by replacement on the mixture of mortar includes $(1,2,3$,4and 5\%) with constant $\mathrm{W} / \mathrm{C}$ ratio and also the amount of the fine aggregate use is 2.75 from the amount of cement. The results show that, the strength of the mortar that consist from colloidal nano materials give better properties than from both mortar with dry nanomaterials replacement and without nano-materials in all test, But the nano-Zirconia materials give good properties up to $2 \%$ in all tests compared with control cement mortar.
\end{abstract}

Keyword: Compressive strength, flexural strength, nano-ZrO ${ }_{2}$, Surface hardness

Paper History :(Received :13-11-2017 ;Accepted :148-2018)

\section{Introduction:}

Recently nano technology is being used or considered for using in many applications and it has received increasing attention in building materials[1]. At present, a significant number of researches dealing with the use of nano particles in cement based materials are available in the literature. However, there is a limited knowledge about the mechanism by which nano particle affects the flow properties, setting times, consistency, workability, rheological, micro structural, mechanical properties etc of cementitious mixes. Furthermore, the literatures appear to be contradictory about the influence of nano particles on the development of such materials

(building materials) [2].As a matter of fact, cement manufacture is an energy intensive

Process and represents $7 \%$ of worldwide energy consumption and $4 \%$ of worldwide industrial $\mathrm{CO}_{2}$ emissions. Therefore, nano-materials when it is used to enhance the properties can improve durability, structural efficiency and strength of cementitious materials. Accordingly, can assist in improving the quality and he lifetime of the structures. The use of nano-materials with cement can reduce carbon dioxide emissions associated with concrete production [3, 4]. However, nano materials are gaining widespread attention to be used in construction sector so as to exhibit enhanced performance of materials in terms of smart functions and sustainable features. The literature showed that the use of nano-material in cementitious system is mainly due to the fact that concrete remains the most complex material and its hydration mechanism is still not completely understood. Therefore, investigators and researchers have been focusing on the substantial scientific background of this essential material at nano level. Furthermore, continuous efforts have been done to improve the durability and the sustainability of concrete, and they have realized significant increment in mechanical properties of cementitious materials by using nano-materials $[5,6]$.

On the other hand, the use of nanoscale industrial waste-based cement replacements can reduce carbon dioxide emissions associated with concrete production [7].The addition of some metal oxide nano-particles to concretes can both reduce the permeability of concrete to ions and increase the strength of concrete, thereby improving durability. The addition of $\mathrm{TiO}_{2}$ nano-particles [8], $\mathrm{Al}_{2} \mathrm{O}_{3}$ nano-particles [9], $\mathrm{ZrO}_{2}$ nano-particles [10], $\mathrm{Fe}_{2} \mathrm{O}_{3}$ nano-particles [11], $\mathrm{SiO}_{2}$ nano-particles [12] and metal oxide containing nano clays [13] have all been shown to improve concrete and/or cement mortar properties. Properties of the cement-based composites made from the CNTs/CNFs-grown cement/mineral admixture were presented. Experimentally, Li et al, [14] studied the mechanical properties of nano- $\mathrm{Fe}_{2} \mathrm{O}_{3}$ and nano$\mathrm{SiO} 2$ cement mortars. The 56-day pore structures of the cement mortars produced by the addition of silica fume and nano- $\mathrm{SiO}_{2}$ (NS), nano- $\mathrm{Al}_{2} \mathrm{O}_{3}$ (NA) and nano- $\mathrm{Fe}_{2} \mathrm{O}_{3}$ (NF) powders. Basically, singular, binary or ternary combinations at different proportions of the binder content were investigated through MIP and BET analysis [15].

Metal oxide nanoparticle addition accelerates reactions during initial hydration thus strengthening cement composites. The metal oxide nanoparticles react with $(\mathrm{CaOH})$ increasing the amount of calcium silicate hydrate (C-S-H) produced, leading to a more compact microstructure. By this means not only decreasing permeability but also improving mechanical properties [16] such as compressive strength, flexural strength and abrasion resistance [17]. The flexural strength of a very thin ferrocement element, by using NSCSC mortar as a replacement to the normal cement mortar, usually used in ferrocement elements was examined. The measured results 
showed an increase the flexural strength of a very thin ferrocement using NSCSC mortar [18]. Zhang and Li [19] found that the addition of $1 \%$ by weight of binder of $15 \mathrm{~nm}$ diameter $\mathrm{TiO} 2$ to concrete refined the pore structure and increased the resistance to chloride penetration by $31 \%$. Shekari and Razzaghi [20] found that the addition of $1.5 \%$ (by weight of cement-based material) of 10-25 $\mathrm{nm} \mathrm{ZrO}_{2}$, $\mathrm{TiO}_{2}, \mathrm{Al}_{2} \mathrm{O}_{3}$ or $\mathrm{Fe}_{3} \mathrm{O}_{4}$ increased the compressive strength and reduced chloride penetration of the concrete by 20 $80 \%$ respectively. Through-depth cracks, of course, severely compromise improvements in impermeability. Oscar et al. [21] studied the effect of the reagglomeration process of Multi-Walled Carbon Nanotubes (MWCNT) dispersions on the activity of silica nanoparticles at early ages when they are combined in cement matrixes.

MWCNT/water/superplasticizer dispersions were produced via sonication and combined with nano silica particles in the mixing water of the cement samples. The methods and theories of in situ growth of CNTs/CNFs on cement/mineral admixture, including chemical vapour deposition method and microwave irradiating conductive polymers method, were summarized [22]. The addition of $\mathrm{SiO}_{2}$ nanoparticles is widely reported to be effective for strengthening concrete; both normally vibrated concrete and self-compacting concrete [23].
The aim of this research involve to study the effect of dispersion methods for nano materials addition to cement mortar, and how it effects on the some mechanical properties and durability of cement mortar when nano material addition by dry and colloidal state.

\section{Experimental Work:}

\section{A- Materials:}

There are many materials which are used to prepare specimens these materials consist of cement, fine aggregate, and water and nano material.

\section{I-Fine aggregate:}

Generally, the fine aggregates made of either crushed stone or natural sand with most

Particles smaller than $(5 \mathrm{~mm})$. The general desirable fineaggregate grading are depending on the required of work. The limits of fine-aggregate grading degree according to ASTM C 33 are generally proportional for general concretes. The ASTM C 33 limits in regarding to sieve size. The sand used in this study is according to the standard specification after its sieved.

.Table : Sand grading and requirements

\begin{tabular}{|c|c|c|}
\hline $\begin{array}{c}\text { Sieve Size } \\
(\mathbf{m m})\end{array}$ & $\begin{array}{c}\text { Accumulative } \\
\text { Passing (\%) }\end{array}$ & $\begin{array}{c}\text { Accumulative } \\
\text { Passing (\%) According to } \\
\text { Limits of I.O.S No.45/1984 }\end{array}$ \\
\hline 4.75 & 100 & $90-100$ \\
2.36 & 100 & $85-100$ \\
1.18 & 87.22 & $75-100$ \\
0.60 & 67.85 & $60-79$ \\
0.30 & 28.53 & $12-40$ \\
\hline
\end{tabular}

\section{II -Nano materials:}

Two types of nano materials are used. The first type is nano-zircona particles $\left(\mathrm{ZrO}_{2}\right)$. It has high purity approach to $(99.9 \%)$, the density is 74.03 , and particle size rounded range between
(15 to 20 nanometer). Nano Shell Company is the source of nano-particles improved from the Arrege Alfrat Company. The some properties of nano- $\mathrm{ZrO}_{2}$ are shown in table (1):

Table (1): Zirconium oxide nano-particles $\left(\mathrm{ZrO}_{2}\right)$ properties

\begin{tabular}{|c|c|c|c|c|c|c|c|c|c|}
\hline \multicolumn{10}{|c|}{ Zirconium oxide nano-particles $\left(\mathrm{ZrO}_{2}\right)$ certificate analysis } \\
\hline $\begin{array}{c}\text { Product } \\
\text { Name }\end{array}$ & symbol & purity & particle size & SSA $\left(\mathbf{m}^{2} / g\right)$ & Color & $\begin{array}{c}\text { BulkDensity } \\
\left(\mathrm{g} / \mathrm{cm}^{\mathbf{3}}\right)\end{array}$ & $\mathrm{Fe}_{2} \mathrm{O}_{3}$ & $\mathrm{SiO}_{2}$ & $\mathrm{Al}_{2} \mathrm{O}_{3}$ \\
\hline $\begin{array}{c}\text { Zirconium } \\
\text { Oxide }\end{array}$ & $\mathrm{ZrO}_{2}$ & $99.9 \%$ & $15-20$ & $160-180$ & white & 2.4 & 0.02 & 0.03 & 0.01 \\
\hline
\end{tabular}




\section{III- Cement:}

In this work the main components in the all mixture Ordinary Portland Cement (type I) was used. The most major and minor components of cement used are described in Table (2). The cement corresponds to the Iraqi
Specification No.5/1984 ordinary Portland cement (type I) from Al Mass Iraqi cement factory, the test was achieved in National Centre for Construction Laboratories (NCCLR) laboratory and research.

Table (2 ): The most major and minor components of ordinary Portland cement (OPC).

\begin{tabular}{|l|c|c|}
\hline Oxides Composition & Oxide content\% & $\begin{array}{c}\text { Limits of Iraqi } \\
\text { Specification No.5/1984 }\end{array}$ \\
\hline $\mathrm{SiO}_{2}$ & 20.26 & - \\
\hline $\mathrm{Al}_{2} \mathrm{O}_{3}$ & 5.50 & - \\
\hline $\mathrm{Fe}_{2} \mathrm{O}_{3}$ & 2.19 & - \\
\hline $\mathrm{CaO}$ & 61.39 & $<5.00$ \\
\hline $\mathrm{MgO}$ & 1.99 & - \\
\hline $\mathrm{SO}_{3}$ & 2.7 & $<4.00$ \\
\hline Free $\mathrm{CaO}$ & 1.12 & $<1.50$ \\
\hline Loss on Ignition & 3.2 & $0.66-1.02$ \\
\hline Insoluble Residue & 0.73 & \\
\hline Lime Saturation Factor & 0.94 & \\
\hline
\end{tabular}

Table (3): Chemical Main Component, Weight \%, for Cement Type (I).

\begin{tabular}{|c|c|c|c|}
\hline Component & Formula & \% by weight of Cement & Limits \\
\hline $\mathrm{C}_{3} \mathrm{~S}$ & $3 \mathrm{CaO} \cdot \mathrm{SiO}_{2}$ & 55.81 & - \\
\hline $\mathrm{C}_{2} \mathrm{~S}$ & $2 \mathrm{CaO} \cdot \mathrm{SiO}_{2}$ & 16.04 & - \\
\hline $\mathrm{C}_{3} \mathrm{~A}$ & $3 \mathrm{CaO} \cdot \mathrm{Al}_{2} \mathrm{O}_{3}$ & 10.87 & $0-15 \%$ \\
\hline $\mathrm{C}_{4} \mathrm{AF}$ & $4 \mathrm{CaO} \cdot \mathrm{Al}_{2} \mathrm{O}_{3} \cdot \mathrm{Fe}_{2} \mathrm{O}_{3}$ & 6.66 & - \\
\hline
\end{tabular}

\section{B- Mortar Preparation (casting and curing):}

The mix proportion of the cement mortar was prepared using (cement: sand ratio) of 1:3 for Iraqi cement standard (IOS NO.8). The water/cement ratio is $(\mathrm{w} / \mathrm{c}=0.5)$. The mix of cement mortar was done by replacement addition of nano-materials particles from the weight of cement. In order to reach complete homogeneity all components were homogenized by electric mixer. The cement mortars were molded into $50 \mathrm{~mm}$ cubes for compressive strength; the prism dimensions $(40 * 40 * 160) \mathrm{mm}^{3}$ for flexural strength test and the molds dimensions for surface hardness test was $(20 * 20 * 20) \mathrm{mm}^{3}$. The specimens are remain in the molds for 24 hours with $100 \%$ relative humidity, and then cured in water for $(3,7,14,21,28,60$ and 91days)

\section{I- Compression Strength test:}

The compression strength tests were done on $50 \mathrm{~mm}$ cube specimens using $(300 \mathrm{KN})$ compressive machine (Tecnotest machine device). The rate of loading on the cubes was $0.5 \mathrm{~mm} / \mathrm{min}$. Three samples were tested for each, and the average strength was recorded.

\section{II-Flexural strength test:}

The flexural test machine was achieved by Tinius Olsen universal material machine device with $(100 \mathrm{KN})$ load is applied in strength of materials laboratory in materials engineering department in materials engineering department/Al-Mustansiriyah

University. The recorded final of the all results obtained was represented the average of flexural strength from many

\section{B- Testing methods:}


prisms. The dimension of prism was done according to (ASTM 348-02) [24].

\section{III-Surface Hardness strength test:}

HPE II is digitalized for decimal precision and great usability.. The force can be evenly applied on the specimen through the help of a patented force grip which by being the center of the instrument body .Shore hardness tester is used for non destructive test. The final results of hardness recorded were the average of the all three result. The test was achieved according to (ASTM D2240) [25].

\section{D-Results and Discussion:}

\section{I-Compressive Results:}

The results of compressive strength specimen's tests for dry and Colloidal nano-materials replacement to cement mortars are illustrated in figures together for purpose to show the effect of nano-materials addition on the compressive strength behavior. The variation of days $(3,7$, 14.21,28,60 and 91 days) with compressive strength of blended mortar for $1 \%$ nano-zirconia $\left(\mathrm{ZrO}_{2}\right)$ replacement was shown in Fig.(2) with Colloidal nano-particles and Fig.(3) with dry nano-particles replacement . Figure (2) illustrate the compressive strength behavior of $1 \%$ nanozirconia $\left(\mathrm{ZrO}_{2}\right)$ replacement addition in dry state, the compressive strength appear few increment in compression strength with different curing time. Also the compressive strength is small increase more than control samples with the same W/C ratio. But, when the loading of nanoZirconia $\left(\mathrm{ZrO}_{2}\right)$ replacement reach to $2 \%$ the compressive strength of mortar with nano addition begin to give better compressive strength behavior compared with control The mechanical property (compressive strength) development at $2 \%$ colloidal nano-Zirconia $\left(\mathrm{ZrO}_{2}\right)$ replacement addition can be seen in figure(3).basically the enhancement in compressive strength because the packing effect of filling the voids that create during the hydration reactions and the materials become more dense and the compressive strength increase.

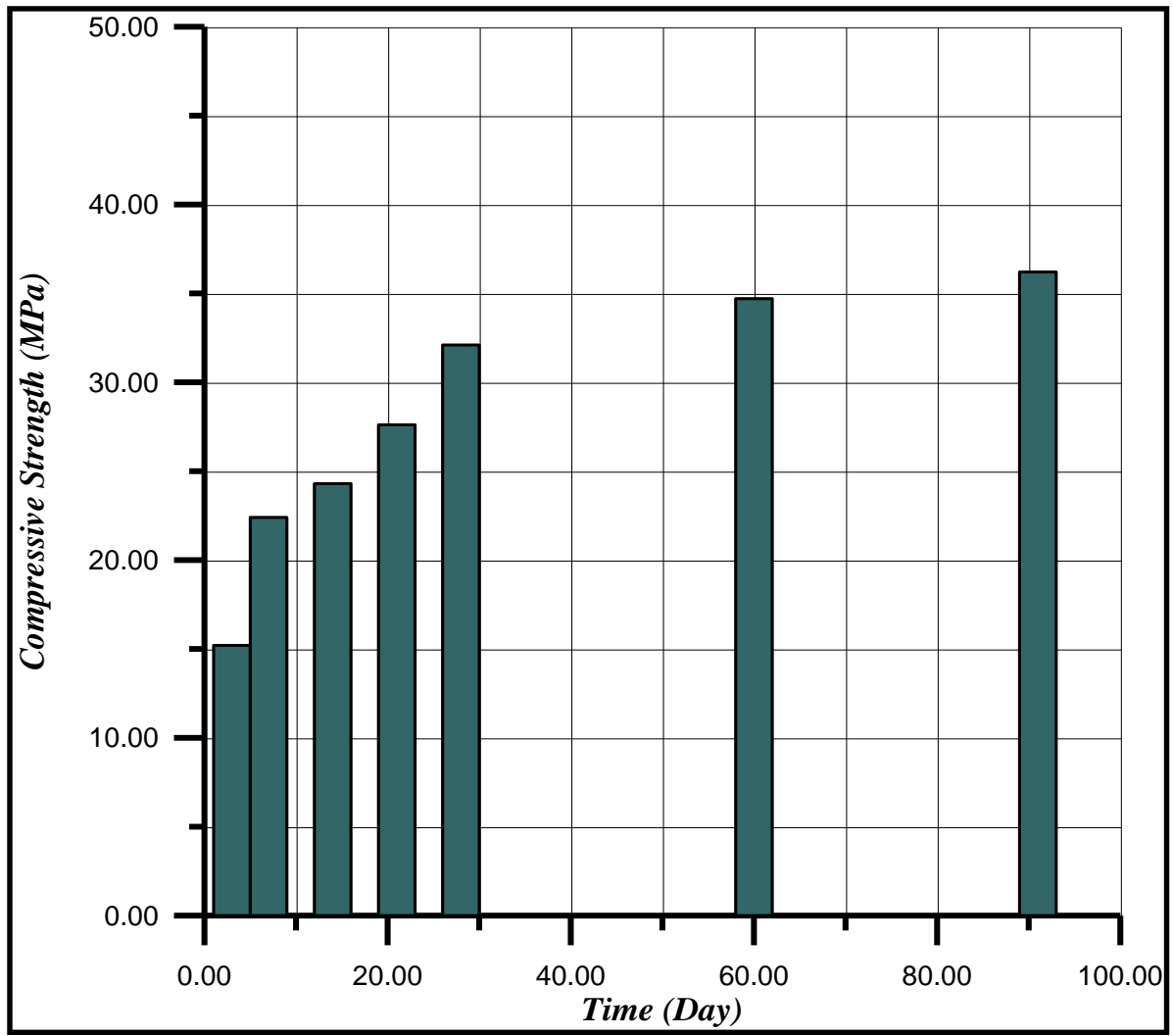

Fig1: Compressive strength without nano- $\mathrm{ZrO}_{2}$ (Control) 


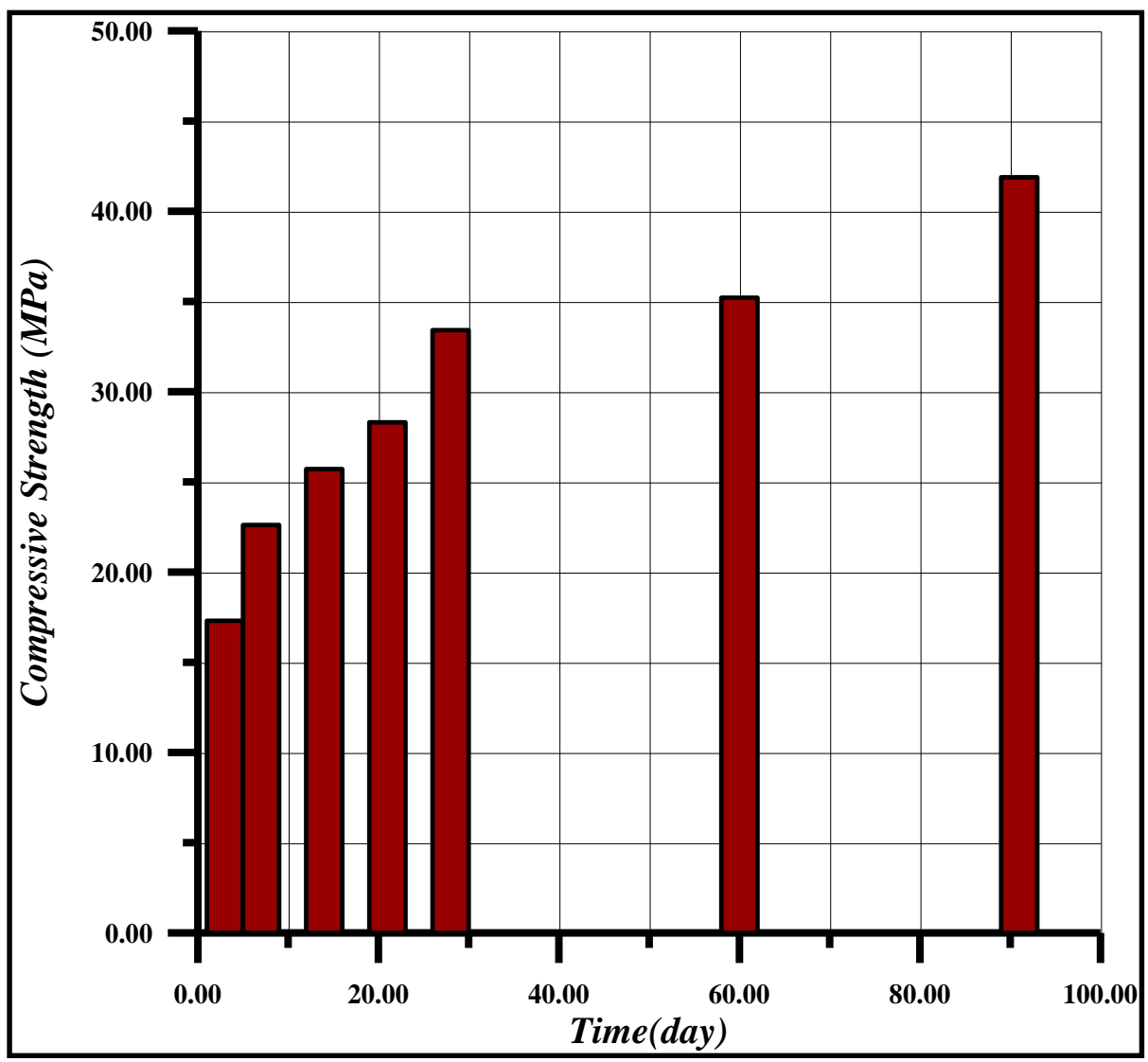

Fig2: Compressive strength for $1 \%$ nano- $\mathrm{ZrO}_{2}$ (Colloidal)

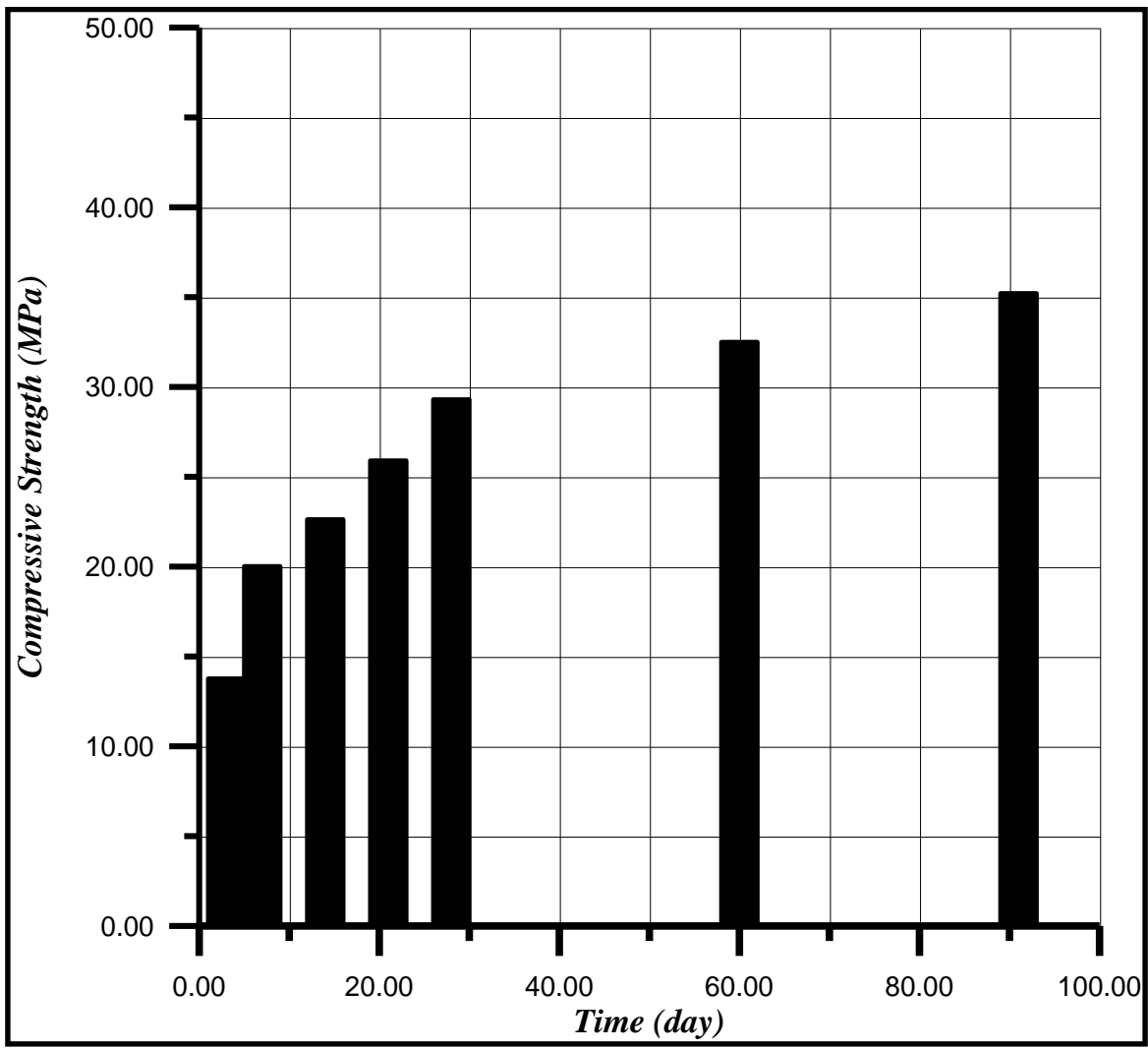


Fig3: Compressive strength for $1 \%$ nano- $\mathrm{ZrO}_{2}$ (Dry)

In samples containing (1\%) dry nano-particles the compressive behaviors illustrate in figure (3) Compressive strength is small increase more than control samples with the same W/C ratio. But, when the increase of nanoZirconia $\left(\mathrm{ZrO}_{2}\right)$ replacement reach to $2 \%$ the compressive strength of mortar with nano addition begin to give better compressive strength behavior compared with control samples but less than colloidal nano-Zirconia $\left(\mathrm{ZrO}_{2}\right)$ replacement because of the different in the dispersion state of particles in the cement mortar mixture and the agglomeration of nano-particles voids are be formed.

With $2 \%$ nano-zirconia replacement the compressive strength increases with curing time increase at constant $\mathrm{W} / \mathrm{C}$ and the compressive strength properties has improved than the control cement mortar at different curing time these behavior was show in figures (3) and (4) for both Colloidal and dry nano-particles replacement respectively. When nano-Zirconia loading is more the amount of Colloidal compressive strength is increasing more than dry nano-particles replacement. With more percentage of nano-Zirconia particles up to $2 \%$ The mechanism of colloidal zirconia-nano-particles effect shown in figure (4), these are described that more Zirconia nano-particles additive in colloidal state has good dispersion of nanoparticles and the mixture of cement mortar become more homogenized and also reduces both the size and amounts of $\mathrm{Ca}(\mathrm{OH})_{2}$ crystals and then the voids are fill in the (C-S$\mathrm{H})$ gel structure. The structures of hydrated becomes denser and compact. Basically the enhancement in compressive strength because the packing effect of filling the voids that create during the hydration reactions $\mathrm{Ca}(\mathrm{OH})_{2}$ consumption by integrated reactions, and the materials become denser and the compressive strength increase. In samples containing (1\%) dry nano-particles the compressive behaviors illustrate in figure (3) Compressive strength is small increase more than control samples with the same $\mathrm{W} / \mathrm{C}$ ratio. But, when the loading of nanoZirconia $\left(\mathrm{ZrO}_{2}\right)$ replacement reach to $2 \%$ was illustrate in fig. (5) , the compressive strength of mortar with nano addition begin to give better compressive strength behavior compared with control samples but less than colloidal nano-Zirconia $\left(\mathrm{ZrO}_{2}\right)$ replacement because of the different in the mechanism dispersion method of nano-particles in the cement mortar mixture and the agglomeration of nanoparticles voids are be formed in the dry state.

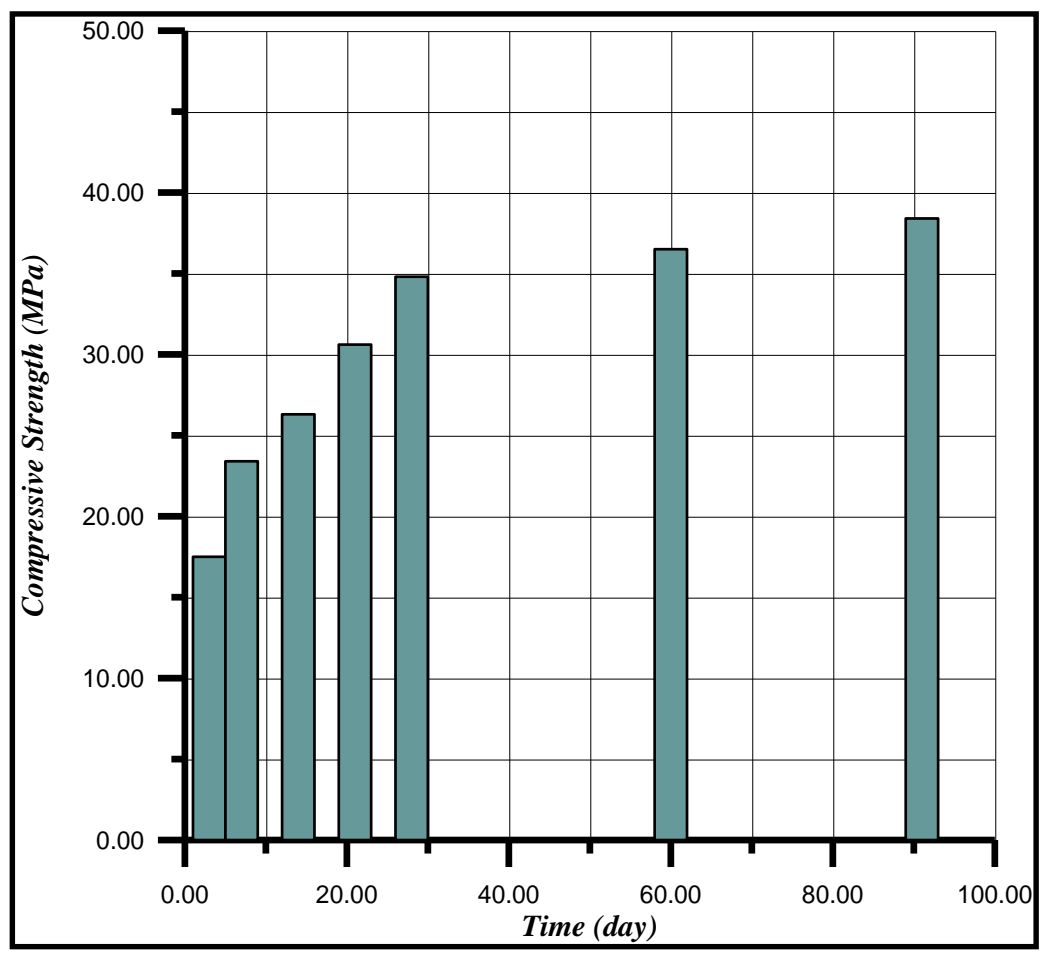

Fig.4: Compressive strength for $2 \%$ nano- $\mathrm{ZrO}_{2}$ (Colloidal) 


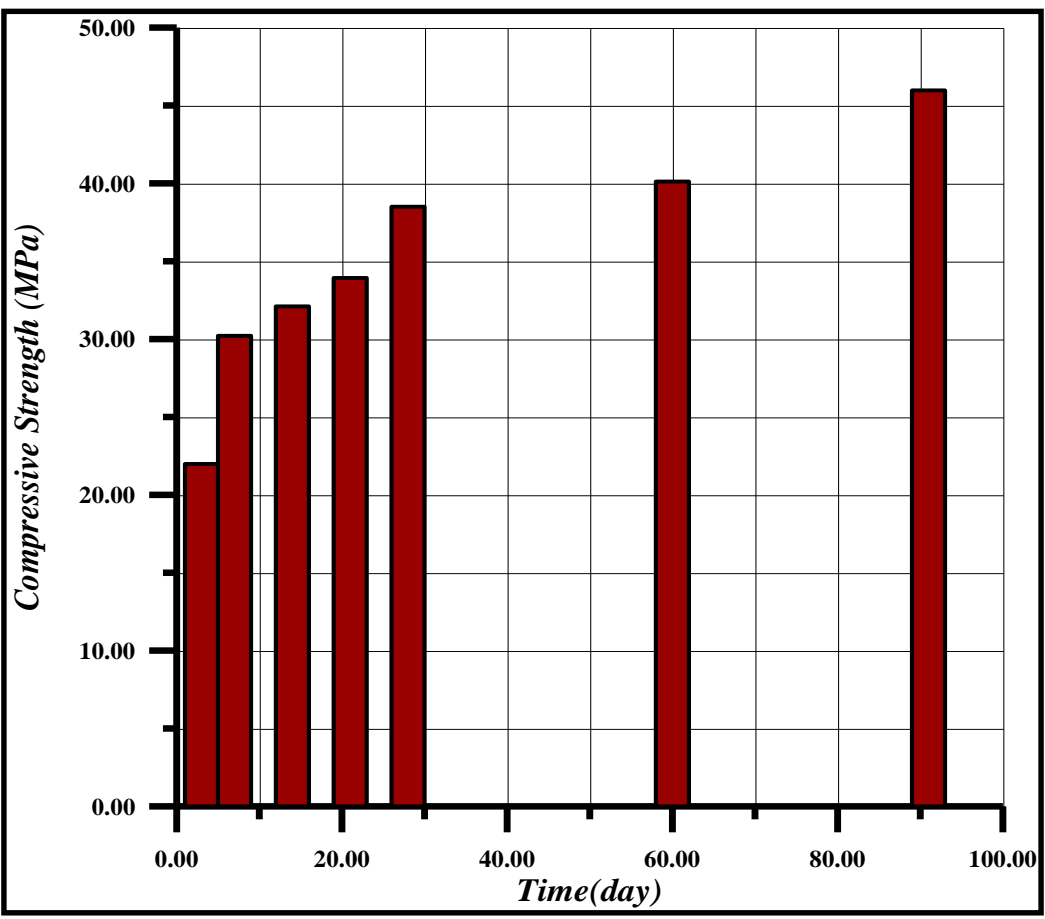

Fig.5: Compressive strength for $2 \%$ nano- $\mathrm{ZrO}_{2}$ (dry)

When nano-particles are more added to the mortar it is not uniformly distributed in cement mortar and due to agglomeration, weak zone appear in the cement mortar. Fig. (6and 7) illustrate the compressive strength behavior of $3 \%$ colloidal and dry nano-Zirconia $\left(\mathrm{ZrO}_{2}\right)$ replacement respectively.

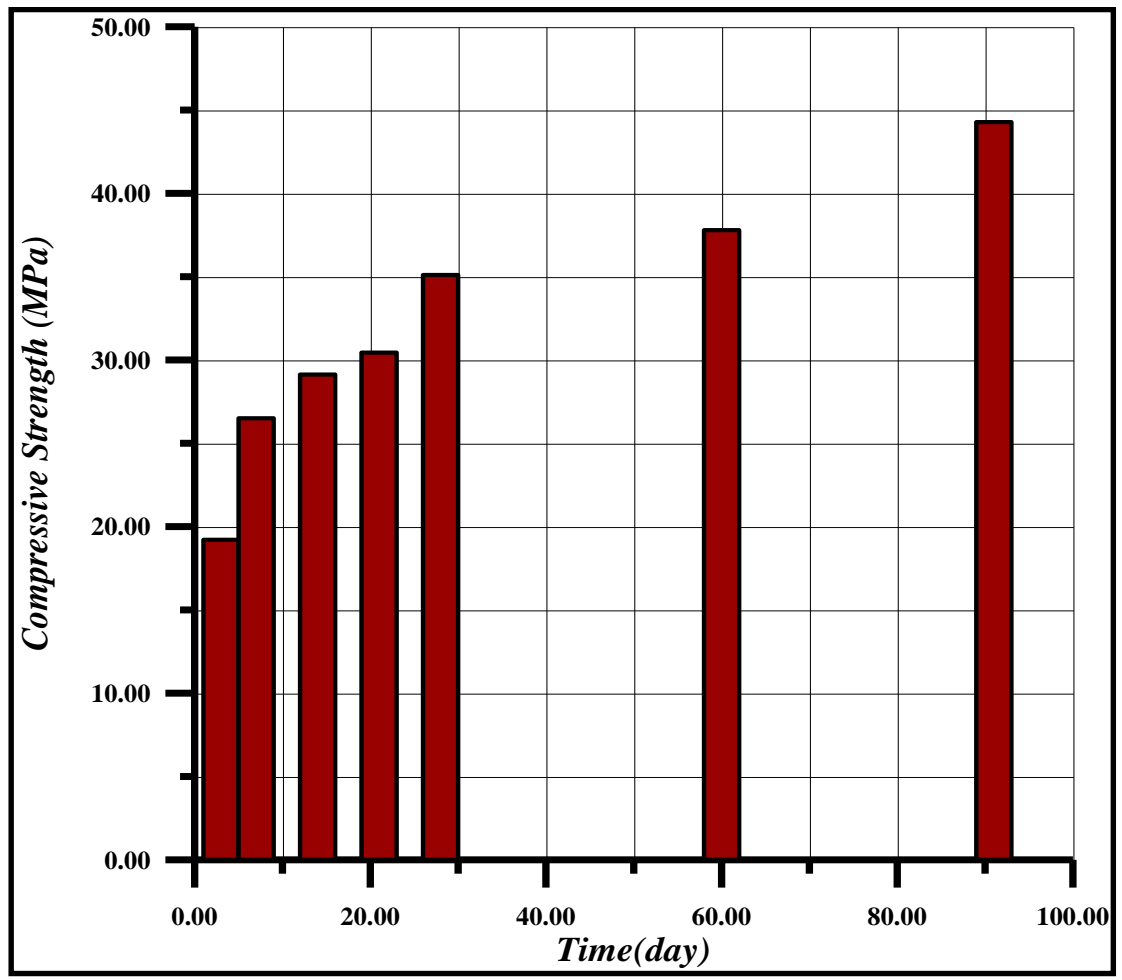

Fig.6: Compressive strength for $3 \%$ nano- $\mathrm{ZrO}_{2}$ (Colloidal) 


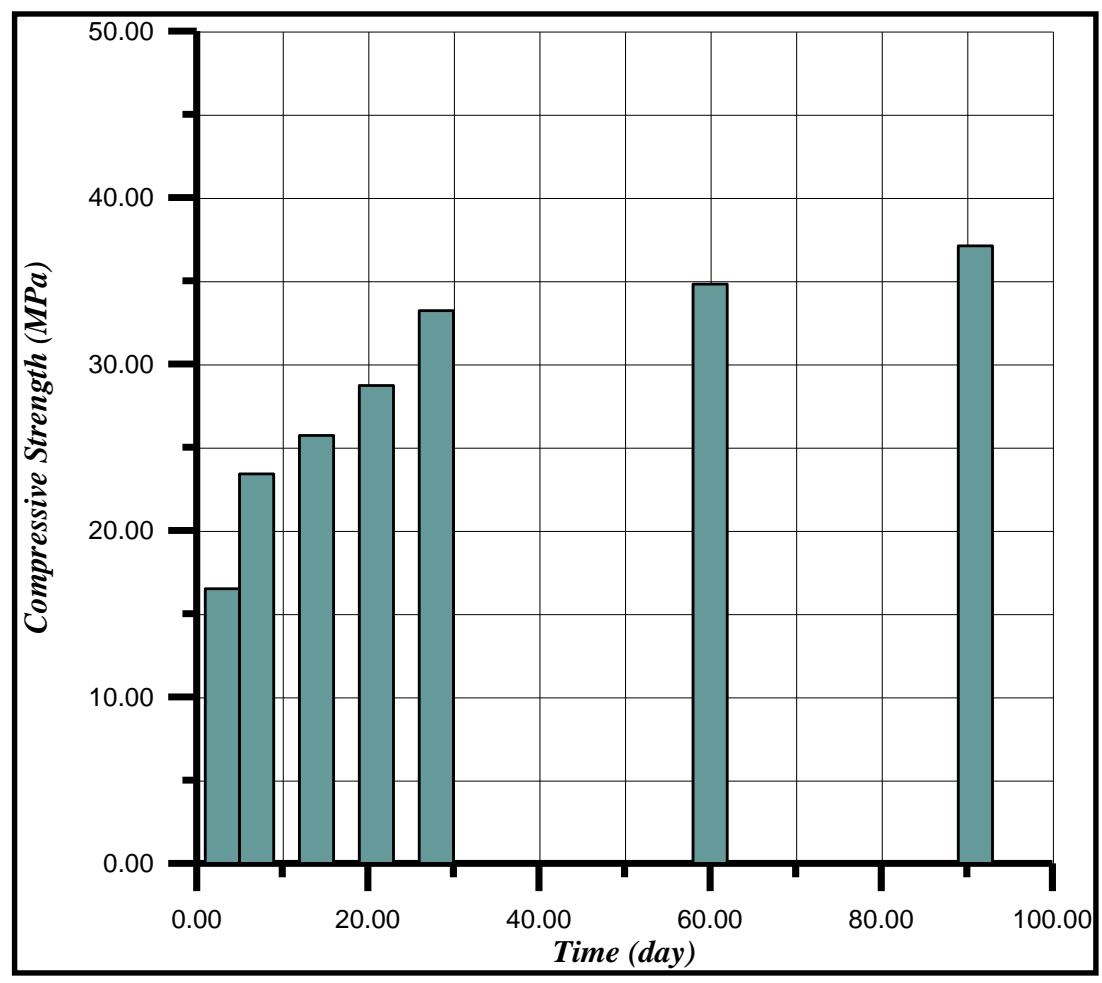

Fig.7: Compressive strength for $3 \%$ nano- $\mathrm{ZrO}_{2}$ (Dry)

The compressive strength appears little increment in compression strength compare with different curing time compared with control specimens. In samples containing (4 and 5\%) nano-particles the compressive behaviors illustrate in figure $(8,9,10$ and 11) because of the agglomeration of nano-particles voids are formed. When nano-particles are over added to the mortar it is not uniformly distributed in cement mortar and due to agglomeration, weak zone appear in the cement mortar.

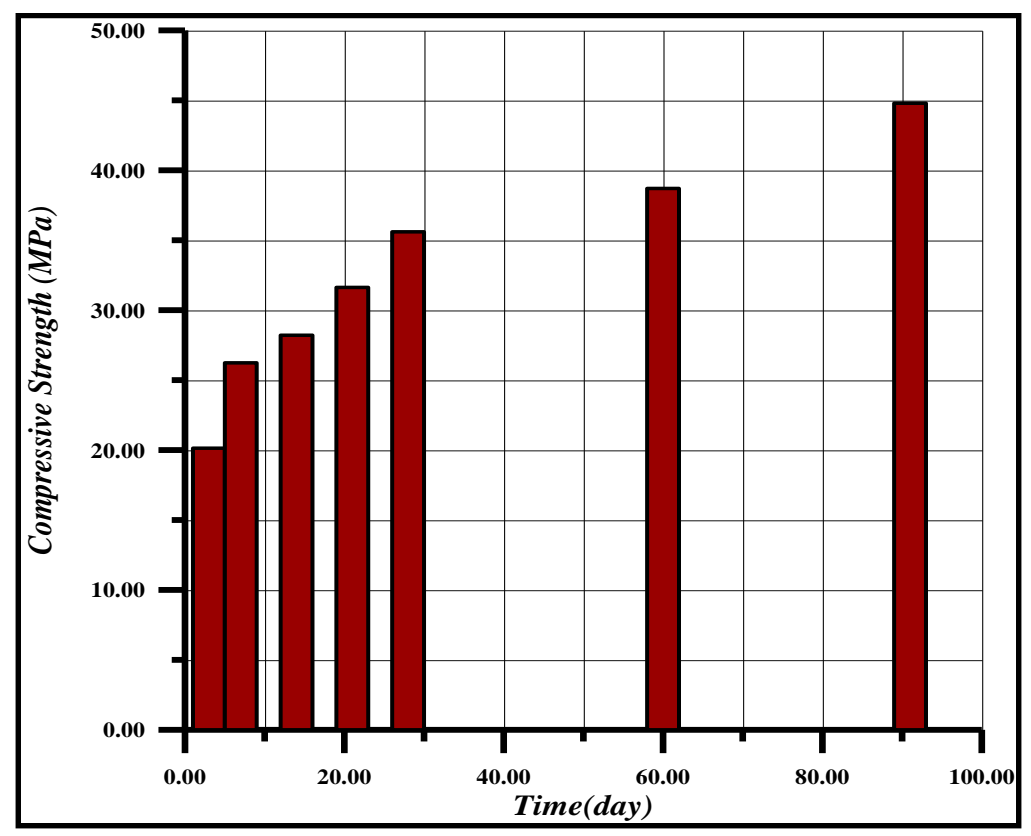


Fig.8: Compressive strength for $4 \%$ nano- $\mathrm{ZrO}_{2}$ (Colloidal)

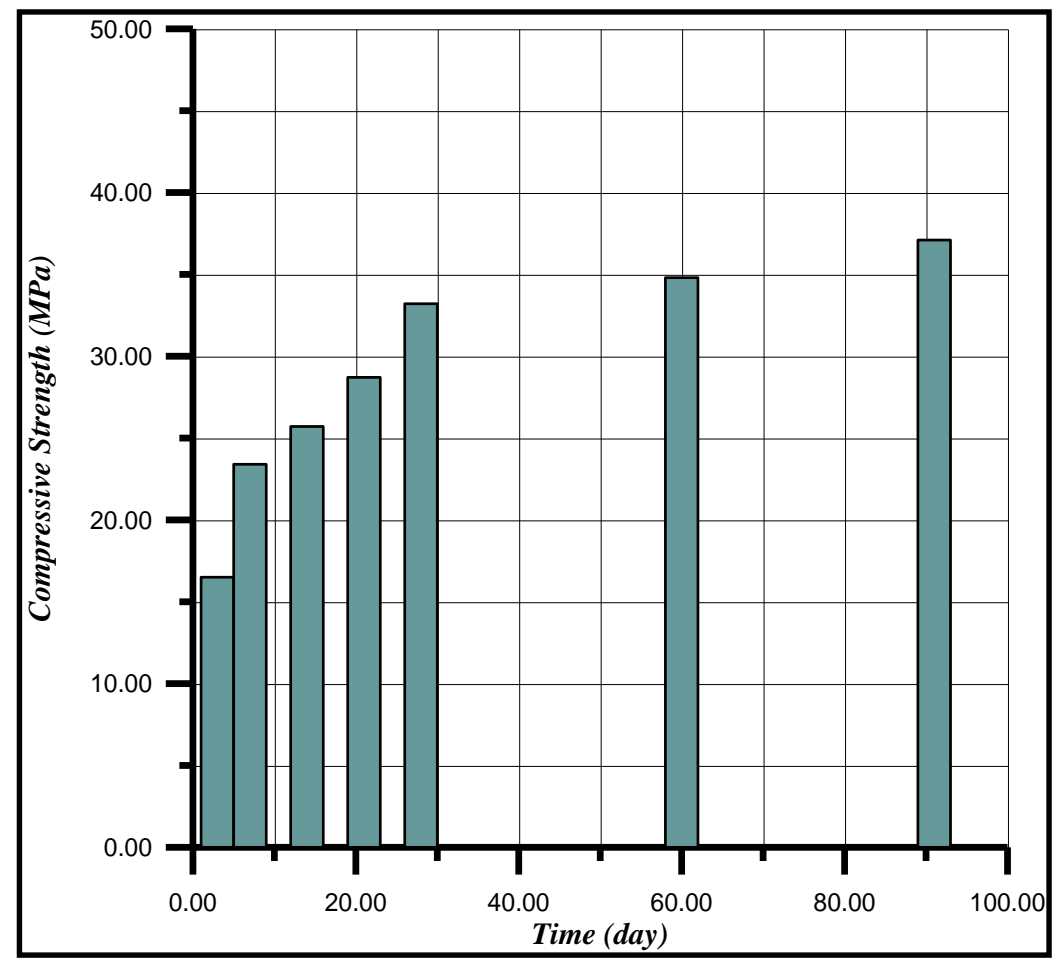

Fig.9: Compressive strength for $4 \%$ nano- $\mathrm{ZrO}_{2}$ (Dry)

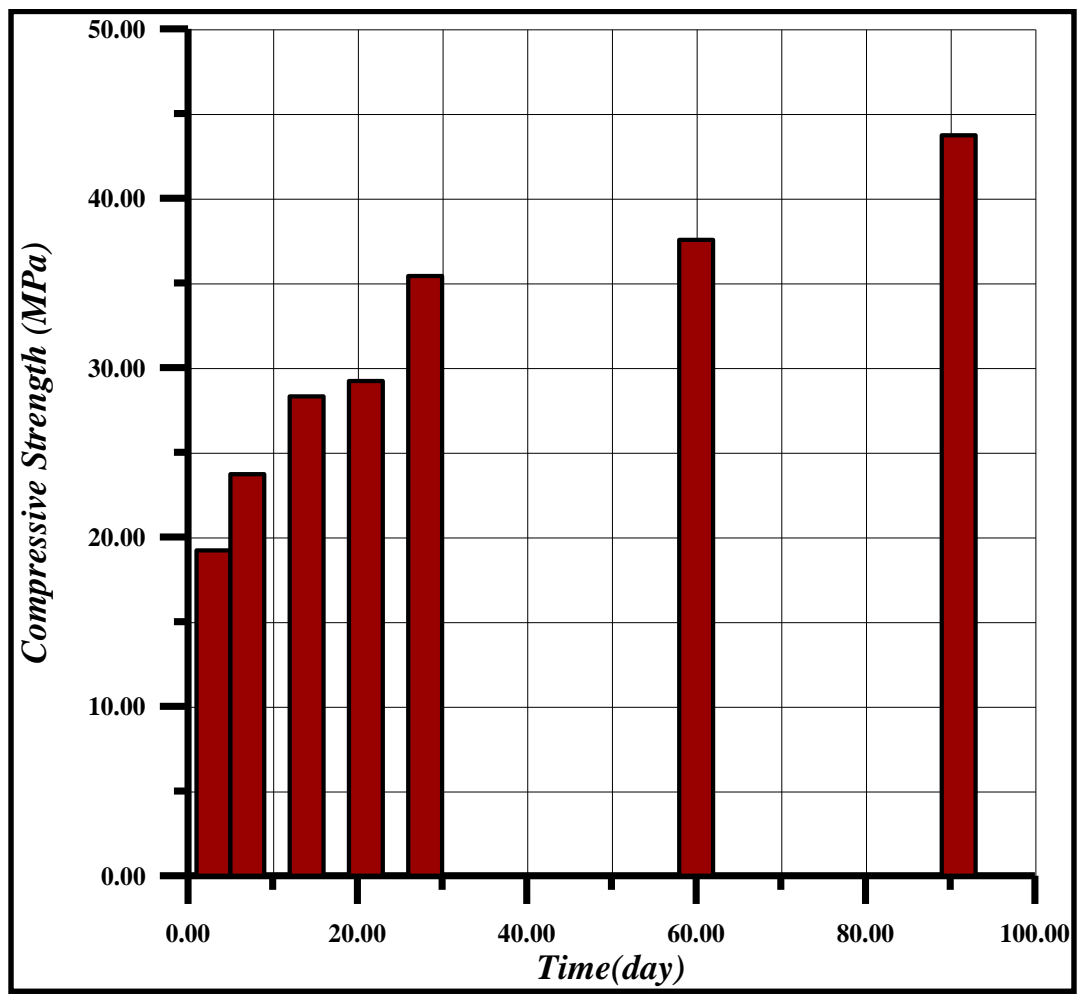

Fig.10: Compressive strength for $5 \%$ nano- $\mathrm{ZrO}_{2}$ (Colloidal) 


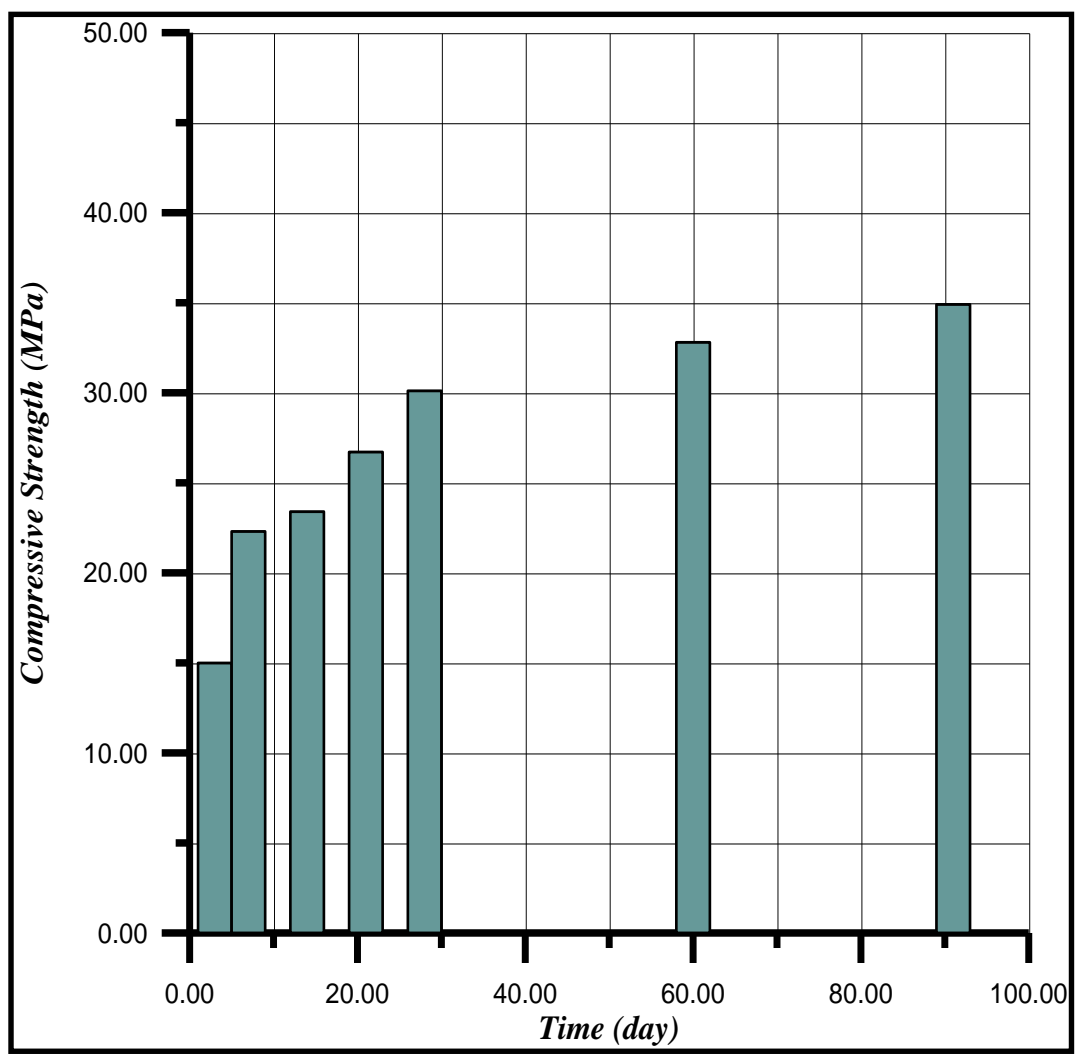

Fig.11: Compressive strength for $5 \%$ nano- $\mathrm{ZrO}_{2}$ (Dry)

\section{II-Flexural strength results}

Mortar prisms tested in accordance with EN 1961 which found the flexural strength and then in compared between control and nano materials addition. Flexural strength of control mortar and with $1 \%$ nano- $\mathrm{ZrO}_{2}$ (dry) and (Colloidal) mortar, at the first time of curing the nano $\mathrm{ZrO}_{2}$ mortar slightly more than that reference mortar (about 2\%) with both nano additives. The effect of $1 \%$ nano $\mathrm{ZrO}_{2}$ up to $2 \%$ nano $\mathrm{ZrO}_{2}$ (Colloidal) the value of flexural strength is more than flexural strength in the dry addition of nano particles in same percentage replacement. The percentage of $(2 \%)$ nano particles replacement can illustrate in figure (13 and 15) respectively for colloidal state and (14 and 16) respectively for dry dispersion. 


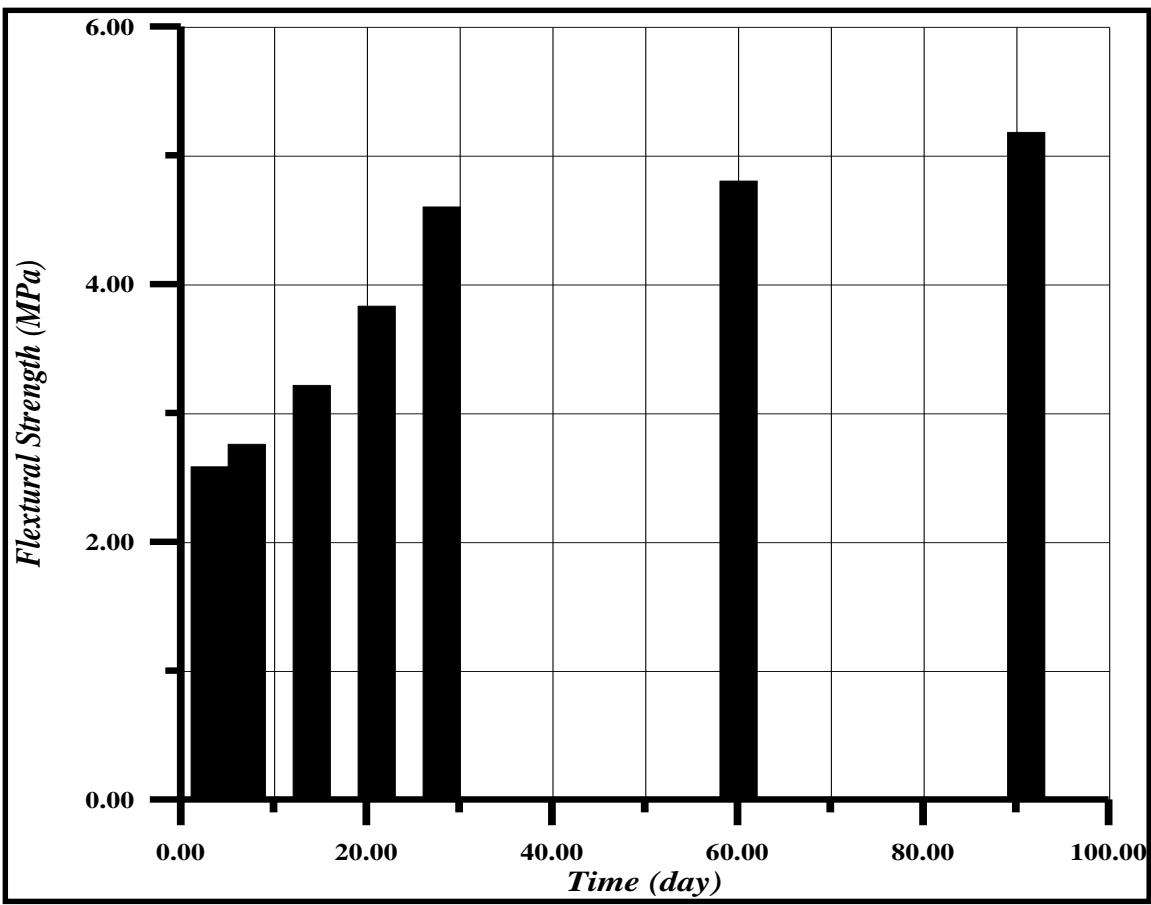

Fig.12: Flexural strength Without nano- $\mathrm{ZrO}_{2}$ addition (control)

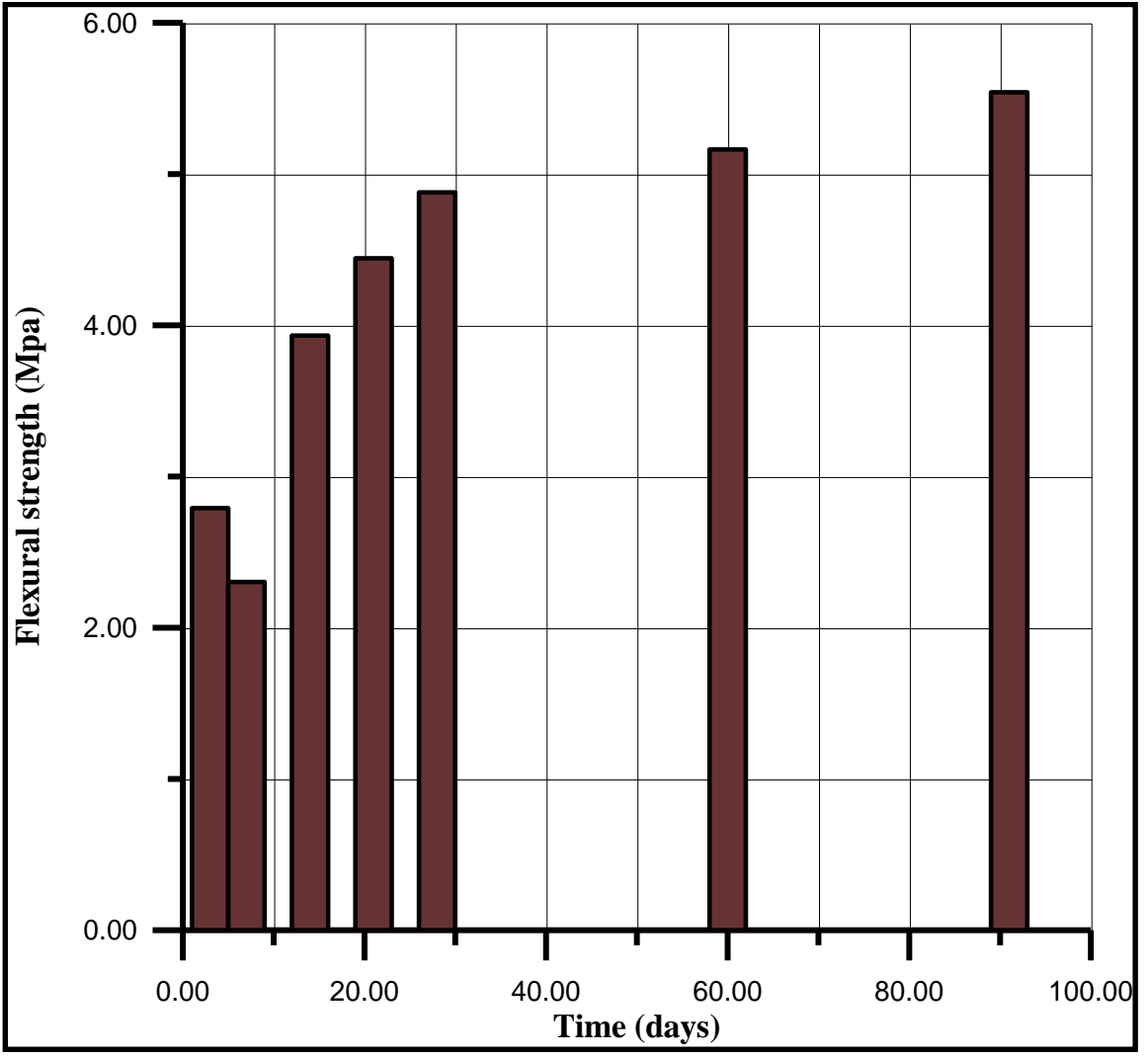

Fig.13: Flexural strength for $1 \%$ nano- $\mathrm{ZrO}_{2}$ (Colloidal) addition 


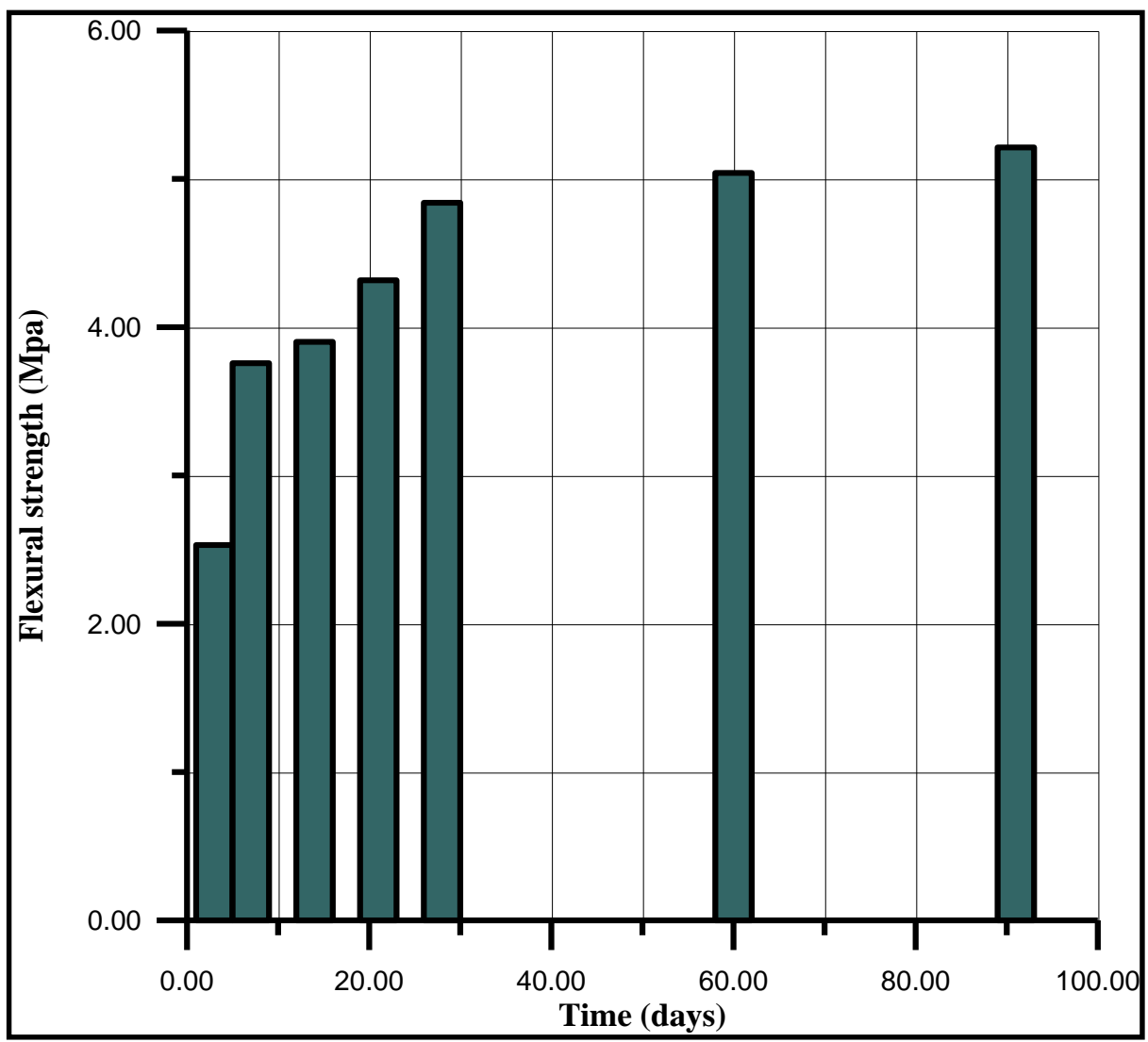

Fig.14: Flexural strength for $1 \%$ nano- $\mathrm{ZrO}_{2}$ (dry) addition

when the proportion of nano addition up to $2 \%$ for nano$\mathrm{ZrO}_{2}$ (Colloidal) it gives an ideal behavior.the flexural strength of mortar with nano- $\mathrm{ZrO}_{2}$ improved up to $2 \%$ this influence can be observed in figure (15 and 16) both dry and colloidal nano-particles replacement respectively. The better dispersion of the particles during the mixing process of nano-particles with mortar mixing which was formed during the hydration process of Portland cement. Which lead to the specially at early age with nano- $\mathrm{ZrO}_{2}$ (Colloidal) related to the high reactivity and less agglomeration (up to $2 \%$ ),

Also that leads to improve the flexural strength by more generation from $(\mathrm{C}-\mathrm{S}-\mathrm{H}) \mathrm{gel}$ and then improve the defects of dispersion method of (Colloidal) $\mathrm{ZrO}_{2}$ nano-particles. In addition, $\mathrm{ZrO}_{2}$ nano-particles recovered the particle packing density of the blended cement, larger pores in the cement paste. However, for the large amount of nano- $\mathrm{ZrO}_{2}$, its lead to non-distribution structure and the rapidly formed hydration products circumference cement grains at early ages will lead to opposite effect at long ages of hydration stage. Then with nano- $\mathrm{ZrO}_{2}$ (colloidal) and (dry) loaded more up to $5 \%$ the flexural strength begin decreases but the amount of flexural strength remains more than control samples. It is may be due to the fact that the amount of $\mathrm{ZrO}_{2}$ nano-particles in both cases present in the mixture was higher than the critical quantity required to combine with the free lime during the cementing hydration process, thus leading to drop in the flexural strength as it replaced a part of the cementing material but did not participated to its strength. Then the behaviors of flexural strength decreases when the nano- $\mathrm{ZrO}_{2}$ (Colloidal) and dry (addition increases up to3, 4 and 5\%.this case observed in figure $(17,18,19,20,21$ and $22 \%)$ respectively. 


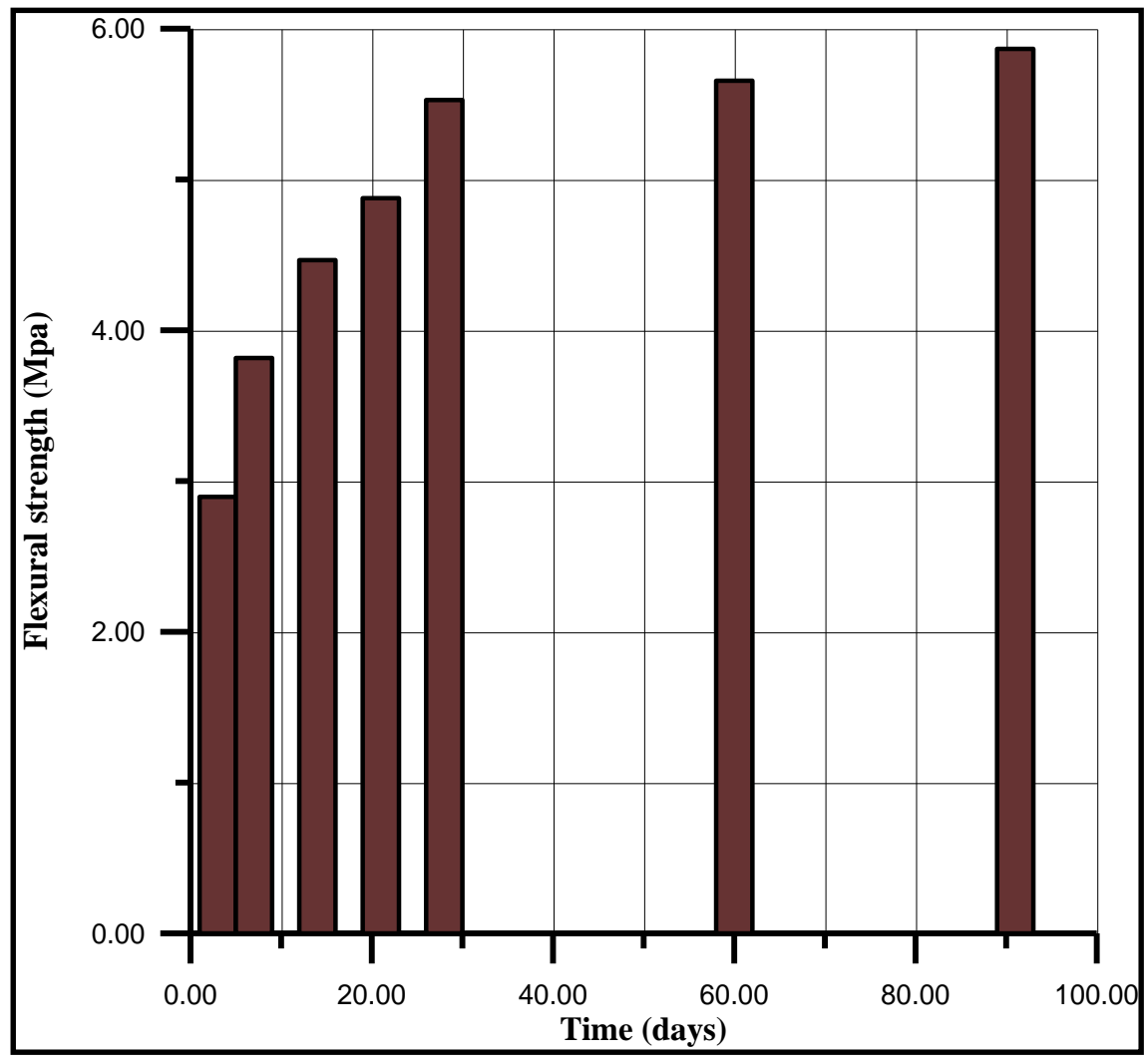

Fig.15: Flexural strength for $2 \%$ nano- $\mathrm{ZrO}_{2}$ (Colloidal)

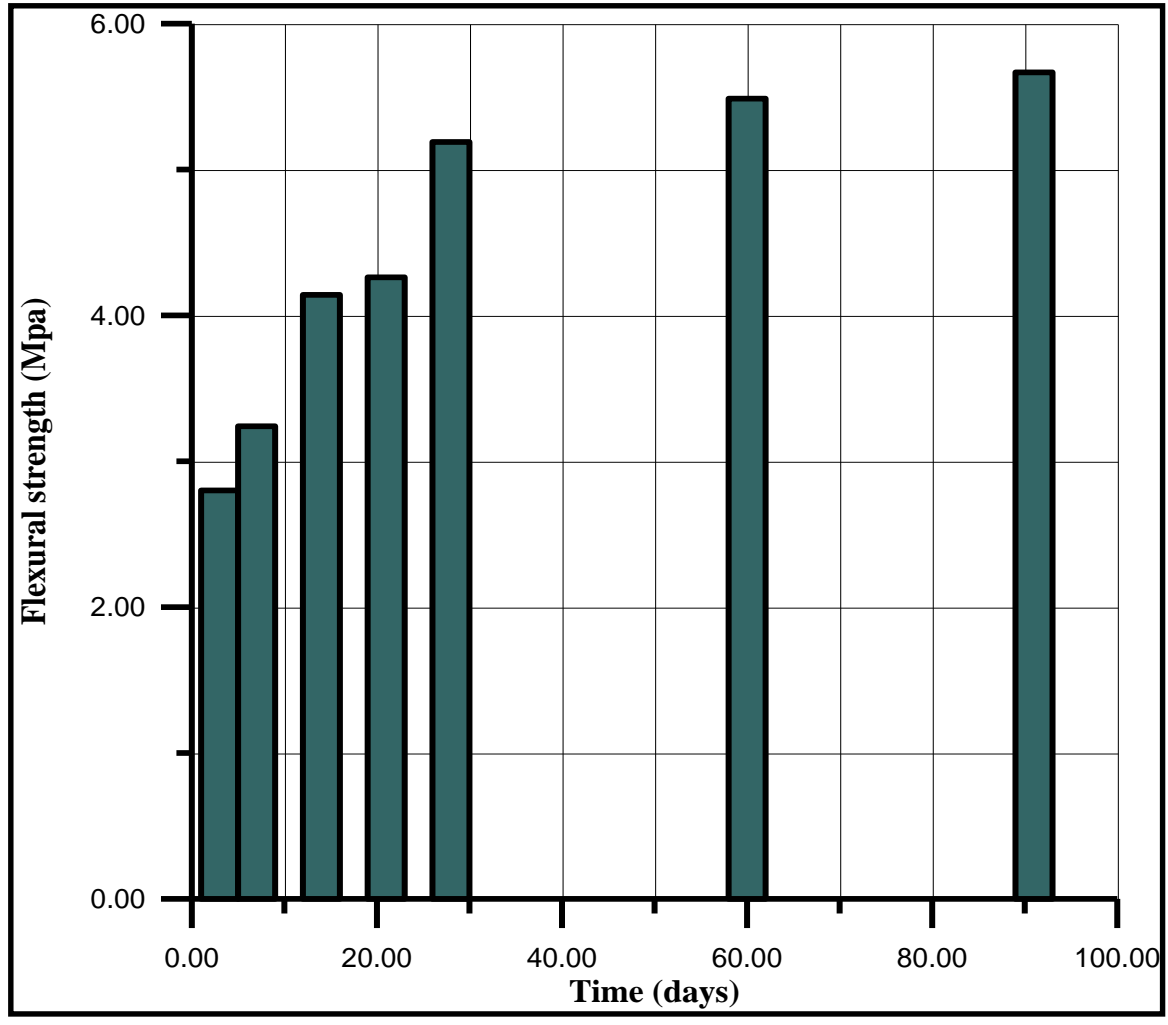

Fig.16: Flexural strength for $2 \%$ nano- $\mathrm{ZrO}_{2}$ (dry) addition 


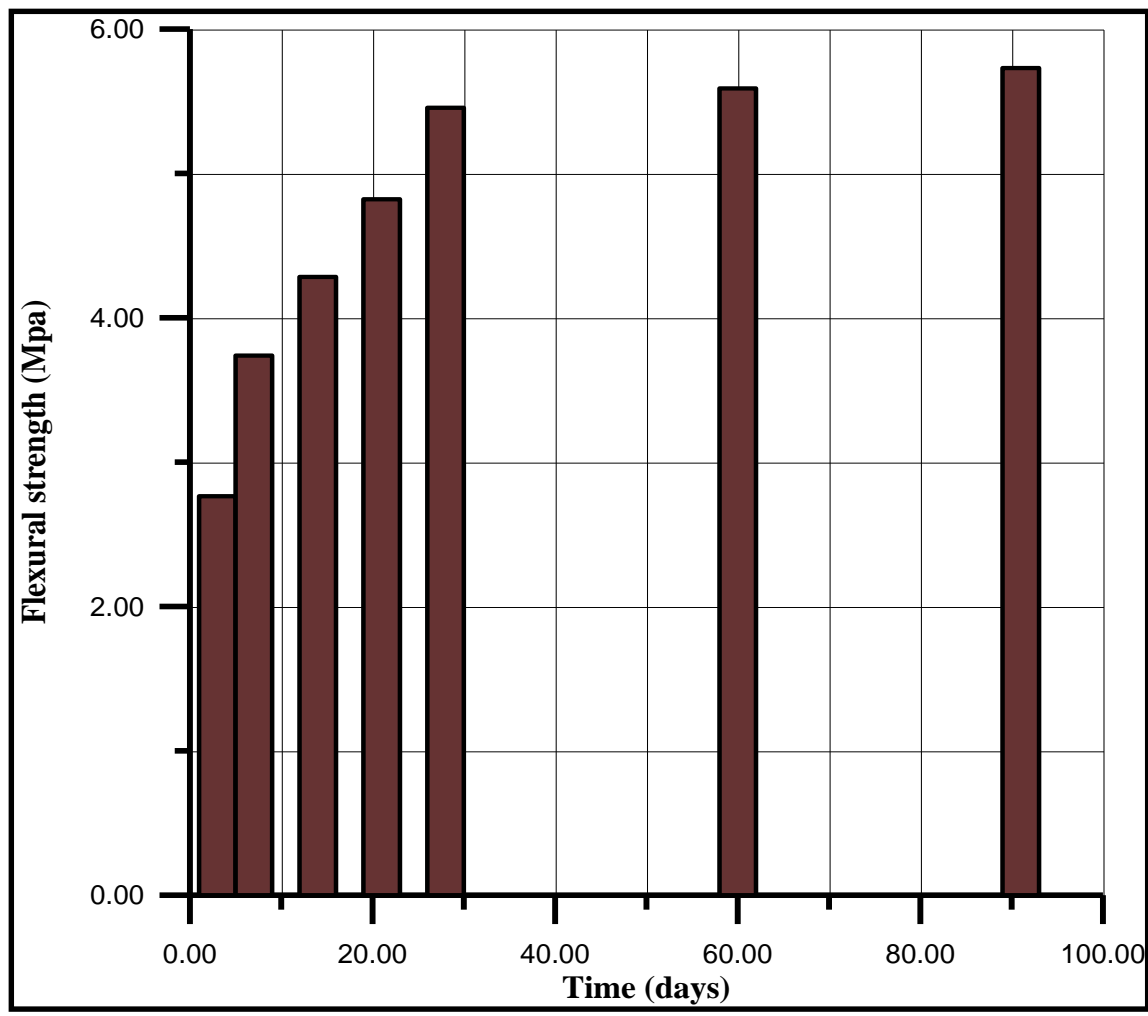

Fig.17: Flexural strength for $3 \%$ nano- $\mathrm{ZrO}_{2}$ (Colloidal)

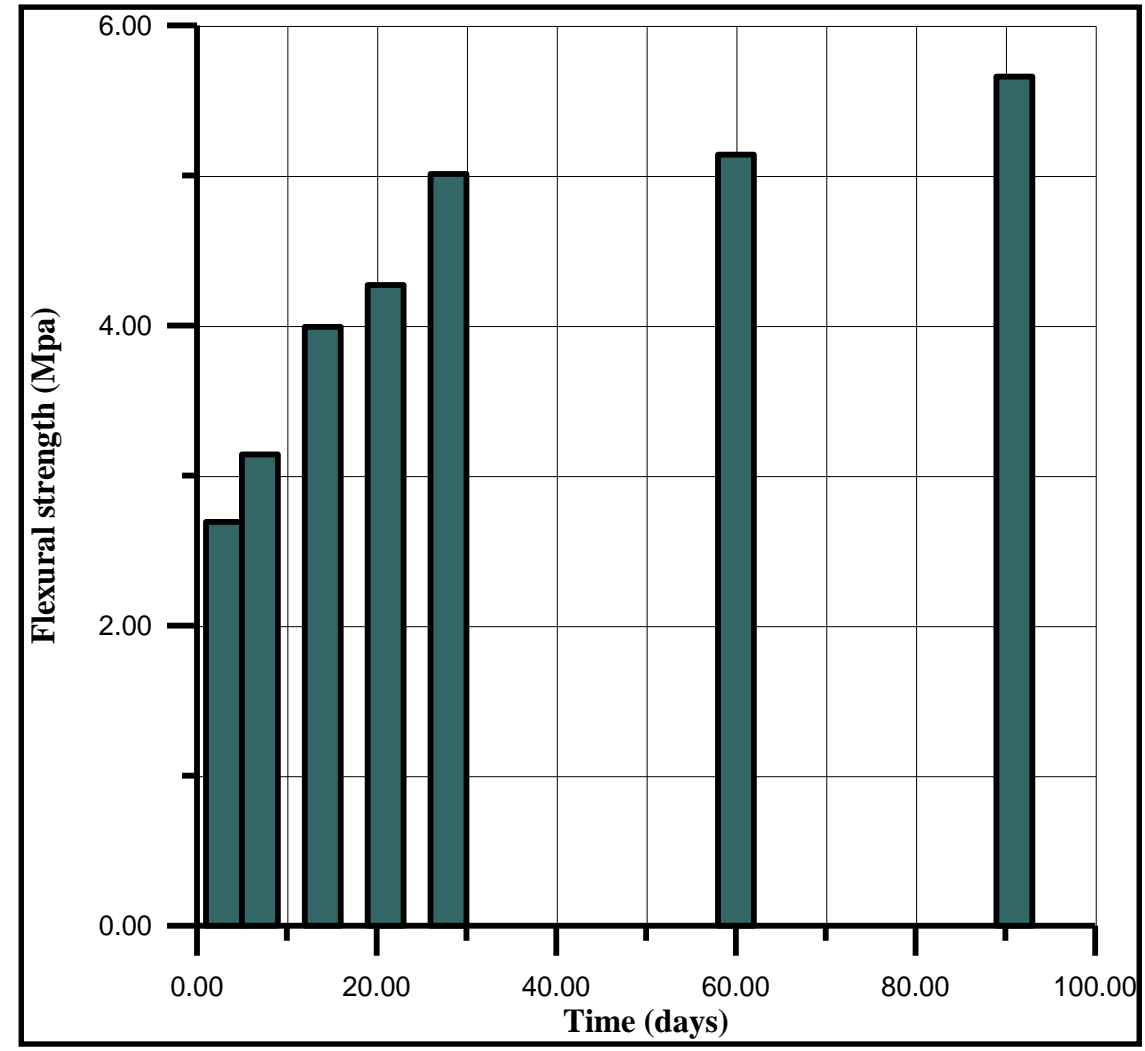

Fig.18: Flexural strength for $3 \%$ nano- $\mathrm{ZrO}_{2}$ (dry) 


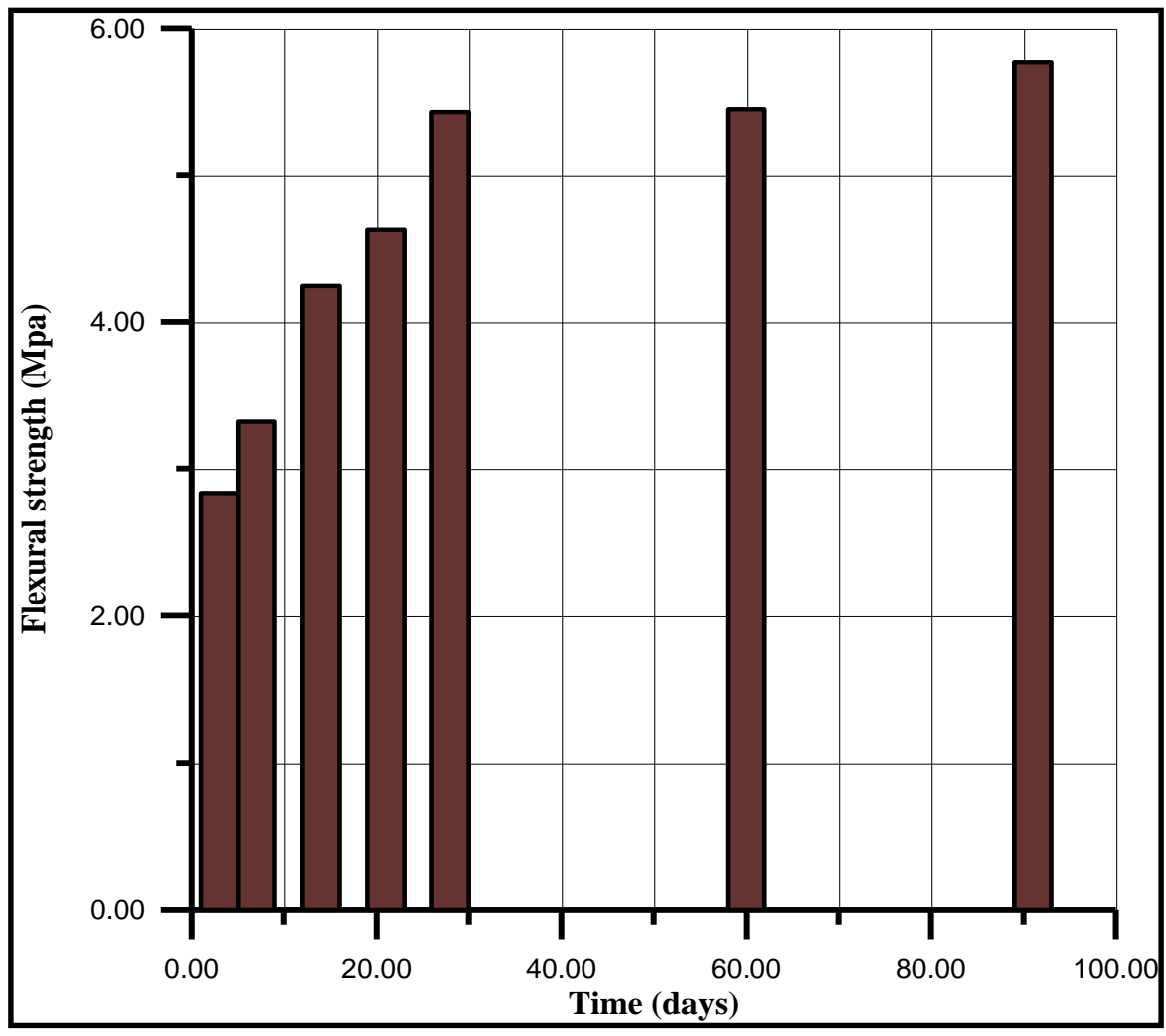

Fig.19: Flexural strength for $4 \%$ nano- $\mathrm{ZrO}_{2}$ (Colloidal)

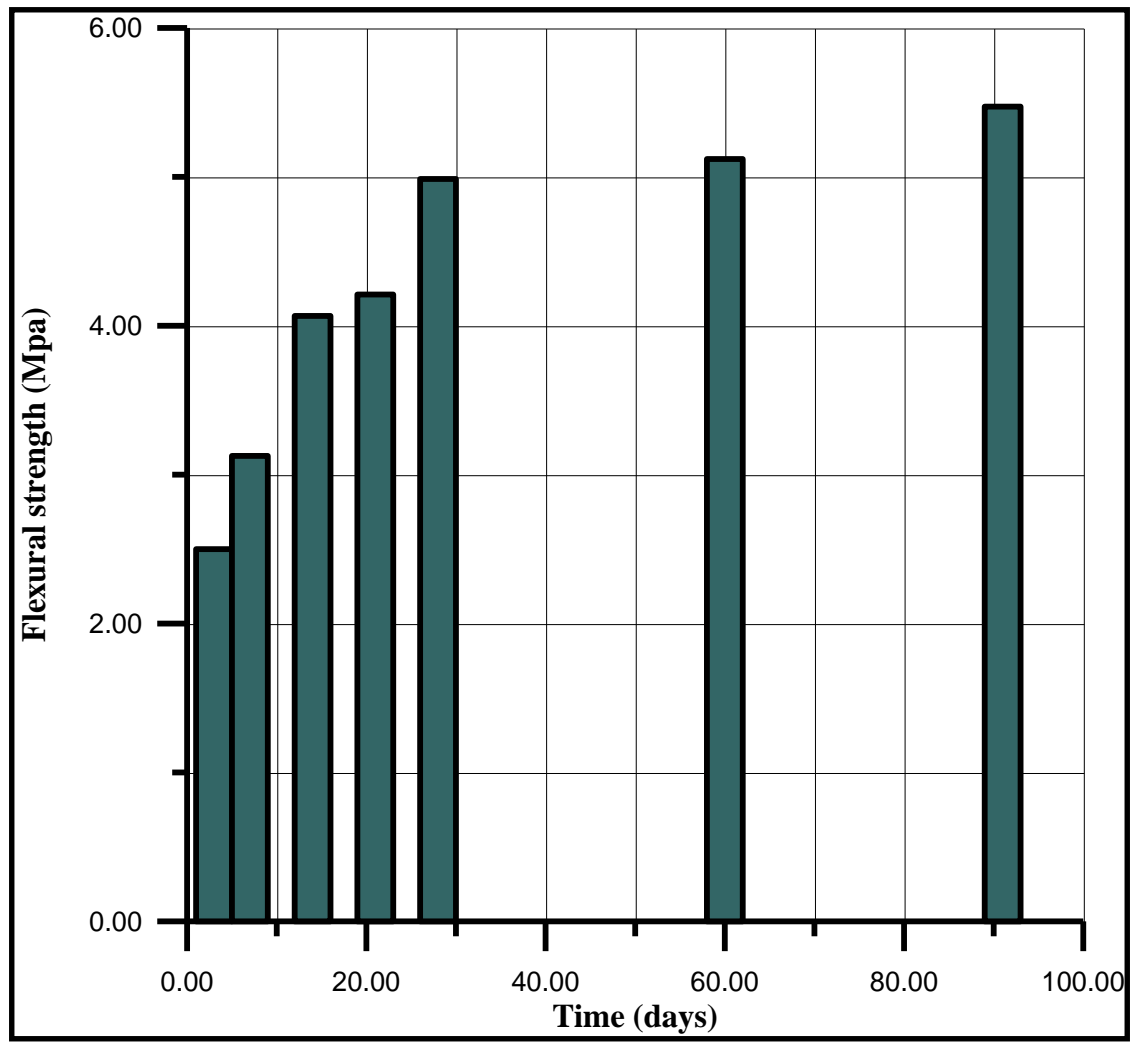

Fig.20: Flexural strength for $4 \%$ nano- $\mathrm{ZrO}_{2}$ (dry) addition 


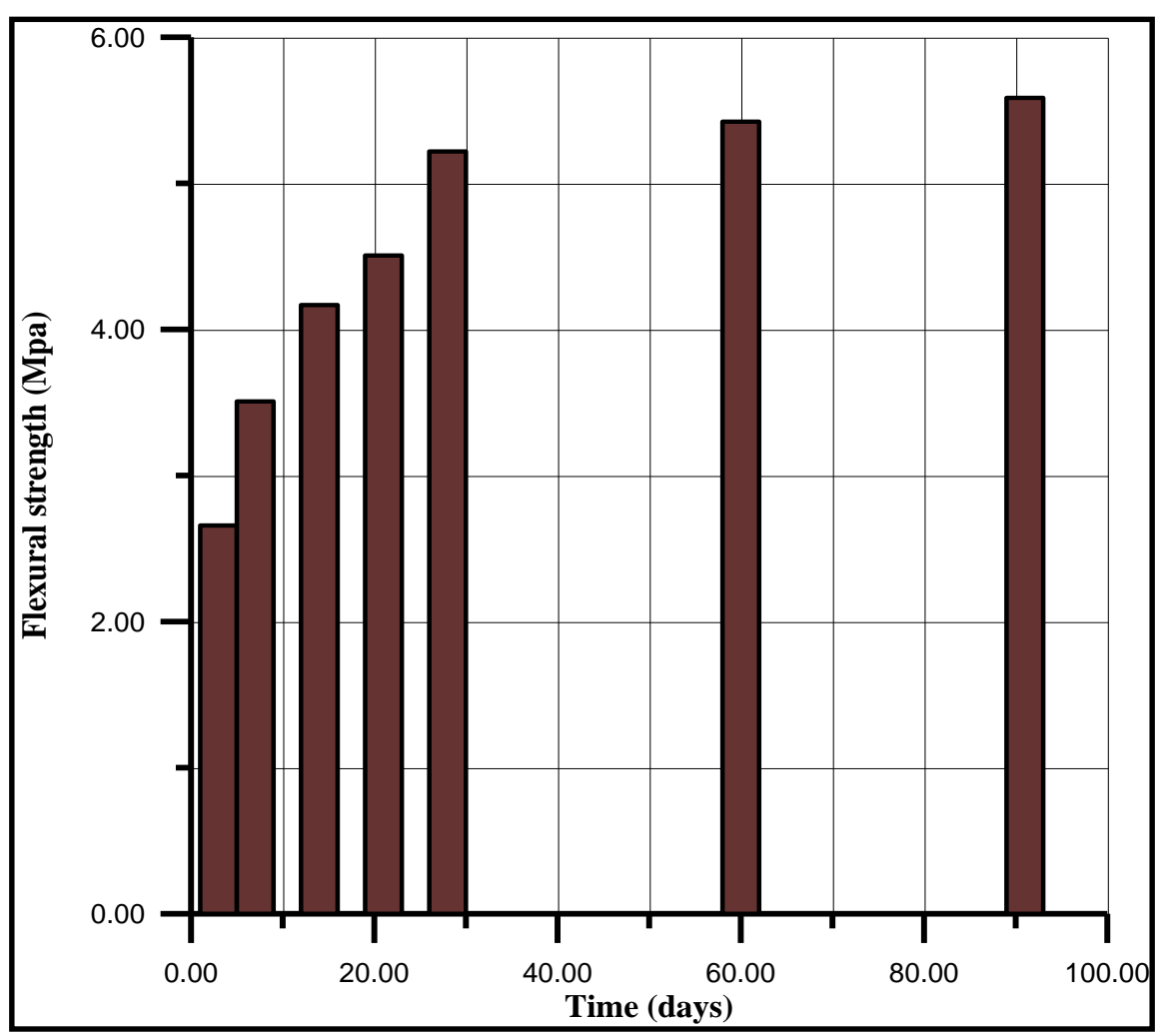

Fig.21: Flexural strength for $5 \%$ nano- $\mathrm{ZrO}_{2}$ (Colloidal)

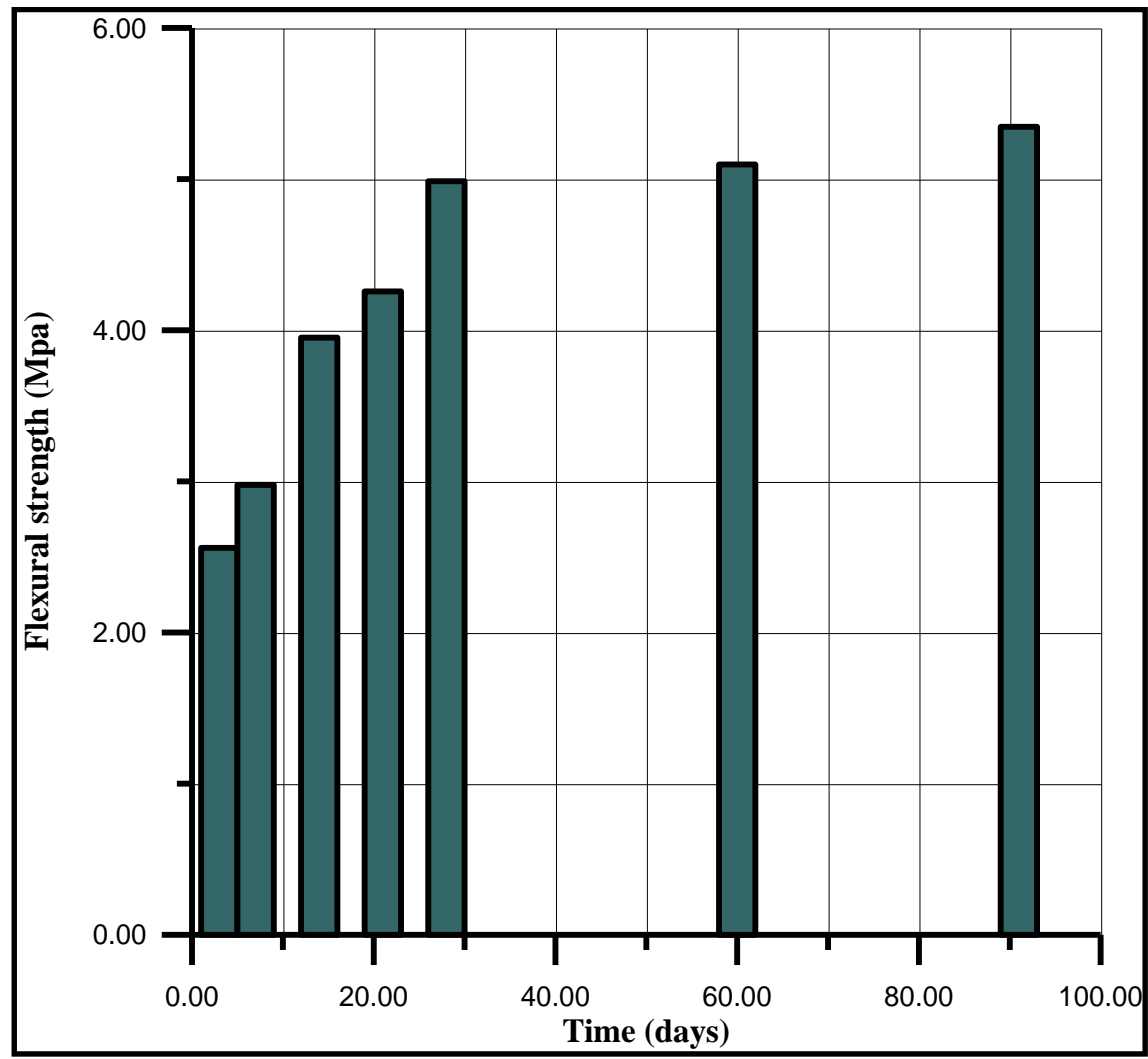

Fig.22: Flexural strength for $5 \%$ nano- $\mathrm{ZrO}_{2}$ (dry) 


\section{III- Surface Hardness analysis}

In this test, samples of mortar were prepared with suitable scale and then tested. The investigation of hardness test is concerned with the development of materials surface. Small samples of cement mortar with and without nano materials additives tested. Figure (23) illustrate control surface hardness test and Figure (24) explain the amount of $(1 \%)$ nano- $\mathrm{ZrO}_{2}$ (Colloidal) replacement addition compared with both dry powder and control specimens. The value of hardness increased for about up to $(2 \%)$ at (91 days). With $(1 \%)$ nano- $\mathrm{ZrO}_{2}$ (dry) the surface hardness value is increase for about $(1 \%)$ than in control ordinary cement mortar, this can be seen in figure (25), as seen in figures, the nano- $\mathrm{ZrO}_{2}$ (Colloidal) mortar remain more than both nano $\mathrm{ZrO}_{2}$ (dry) and control samples. This nano materials makes the mortar more denser with low in voids.

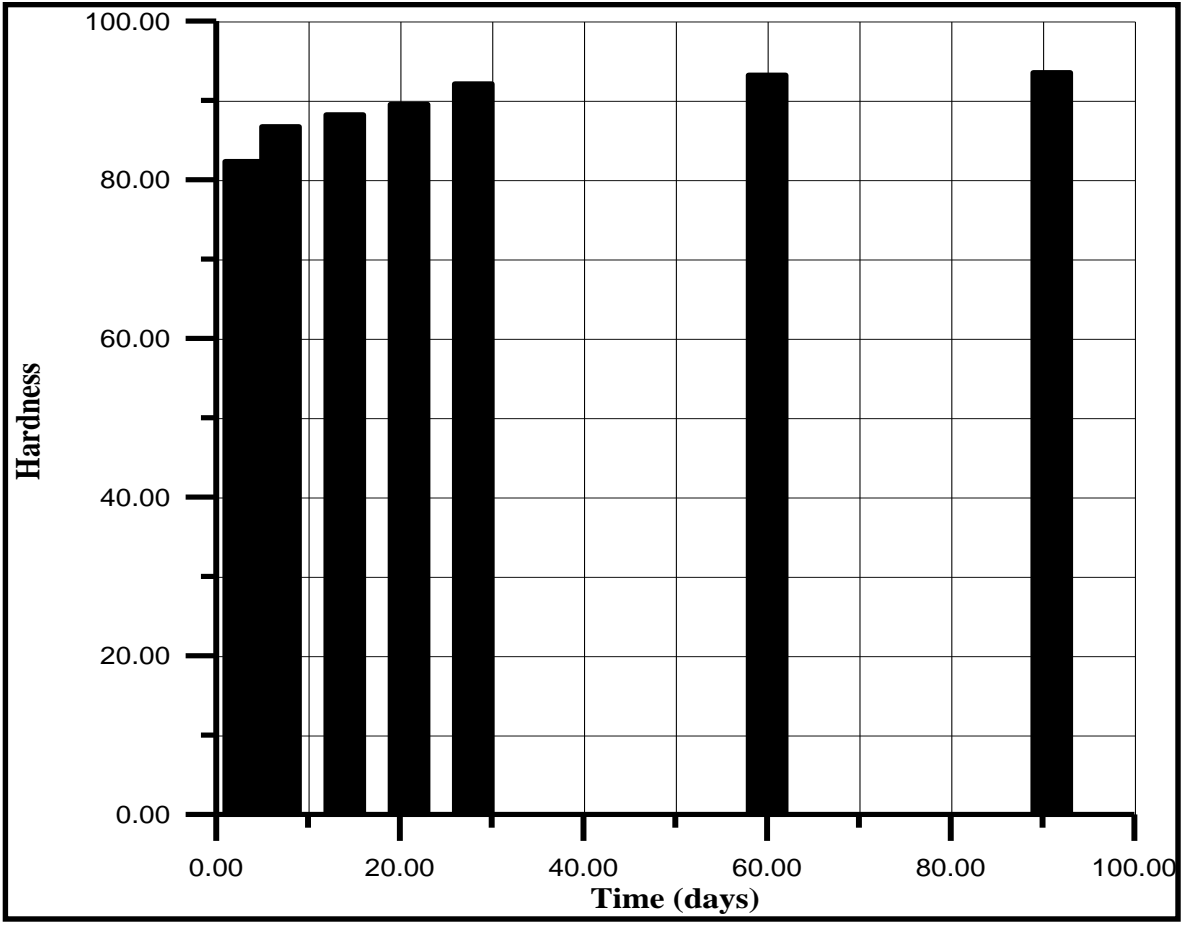

Fig.23: Surface hardness for (Control) without nano- $\mathrm{ZrO}_{2}$

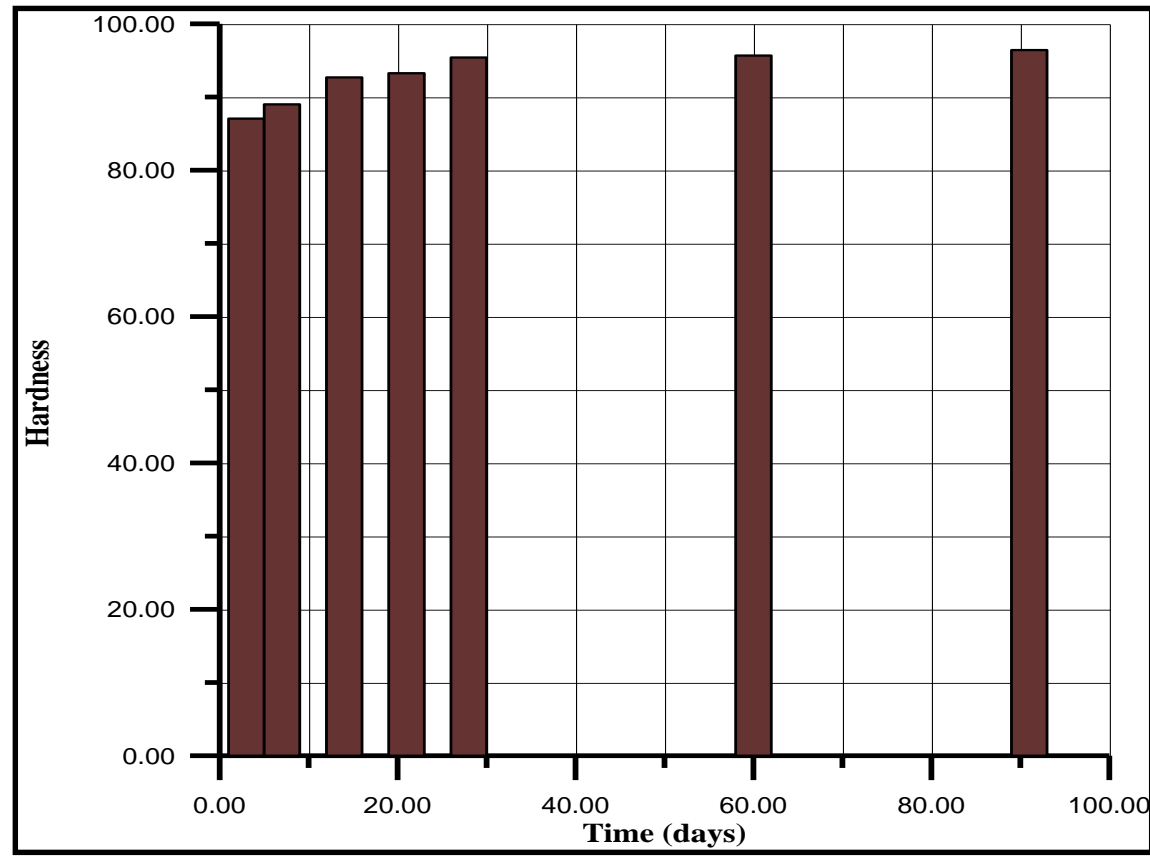

Fig.24: Surface hardness for $(1 \%)$ nano- $\mathrm{ZrO}_{2}$ (Colloidal) 


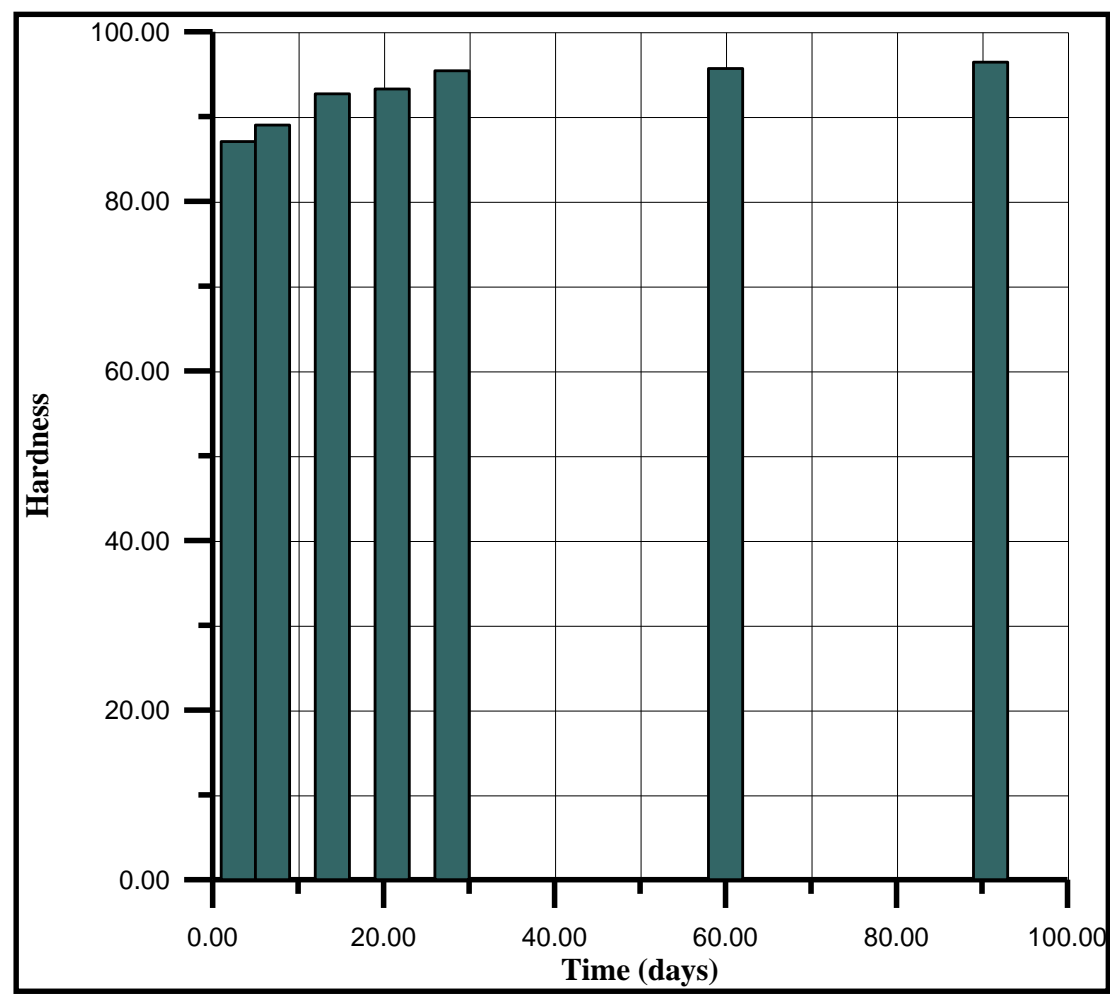

Fig.25: Surface hardness for $1 \%$ nano- $\mathrm{ZrO}_{2}$ (dry)

Increasing in the values of hardness can be seen figures (26) for $(2 \%)$ nano- $\mathrm{ZrO}_{2}$ (Colloidal) addition respectively. When nano- $\mathrm{ZrO}_{2}$ (Colloidal) content was increased to the cement mortar content up to $2 \%$, the total specific pore volumes of cement mortar can be decreased and the most probable pore diameters of mortar shift to smaller pores and fall in the range of less harmful pores or even harmless pores, which indicates that the addition of $\mathrm{ZrO}_{2}$ nanoparticles improve the structure of cement mortar. For ( $(2 \%)$ nano $\mathrm{ZrO}_{2}$ (dry) addition), as seen in figure (27).

With the increase of nano $\mathrm{ZrO}_{2}$ (Colloidal) particles quantity up to (2\%), microstructure was improved completely and achieved better density. because of the phenomenon that $\mathrm{ZrO}_{2}$ nano particles and good dispersion mechanism are characterized by their unique surface effects, smaller particle size, and higher surface energy High. The mechanism of the $\mathrm{ZrO}_{2}$ nano particles in improving the pore structure of cement mortar
Can be attributed to the fact that the nano particles are uniformly dispersed in cement mortar and each particle is contained in a cube pattern. Amount of nano $\mathrm{ZrO}_{2}$ particles as more than $(5 \%)$ will lead to make the cement mortar matrix is able to dense in a way that make the permeability reduction observed clearly. So, the performance of nano materials $\left(\mathrm{ZrO}_{2}\right)$ is clearly in the mortar durability case. This was found in samples containing (nano $\mathrm{ZrO}_{2}$ particles and because of the agglomeration of nano particles voids were create. Figures (27) and figure (29) illustrate the harness behavior at (4 and $5 \%$ ) nano $\mathrm{ZrO}_{2}$ (Colloidal) particles addition. Using nano $\mathrm{ZrO}_{2}$ up to $(5 \%)$ will cause the hardness behavior to decrease; these can be seen in figures (26), (28) and (30) represent with (3, 4 and 5\%) nano $\mathrm{ZrO}_{2}$ (dry) replacement addition respectively which effects on hardness behavior. These nano particles will cause uniformly distribute in cement mortar and due to agglomeration, weak zone appears in the cement mortar. 


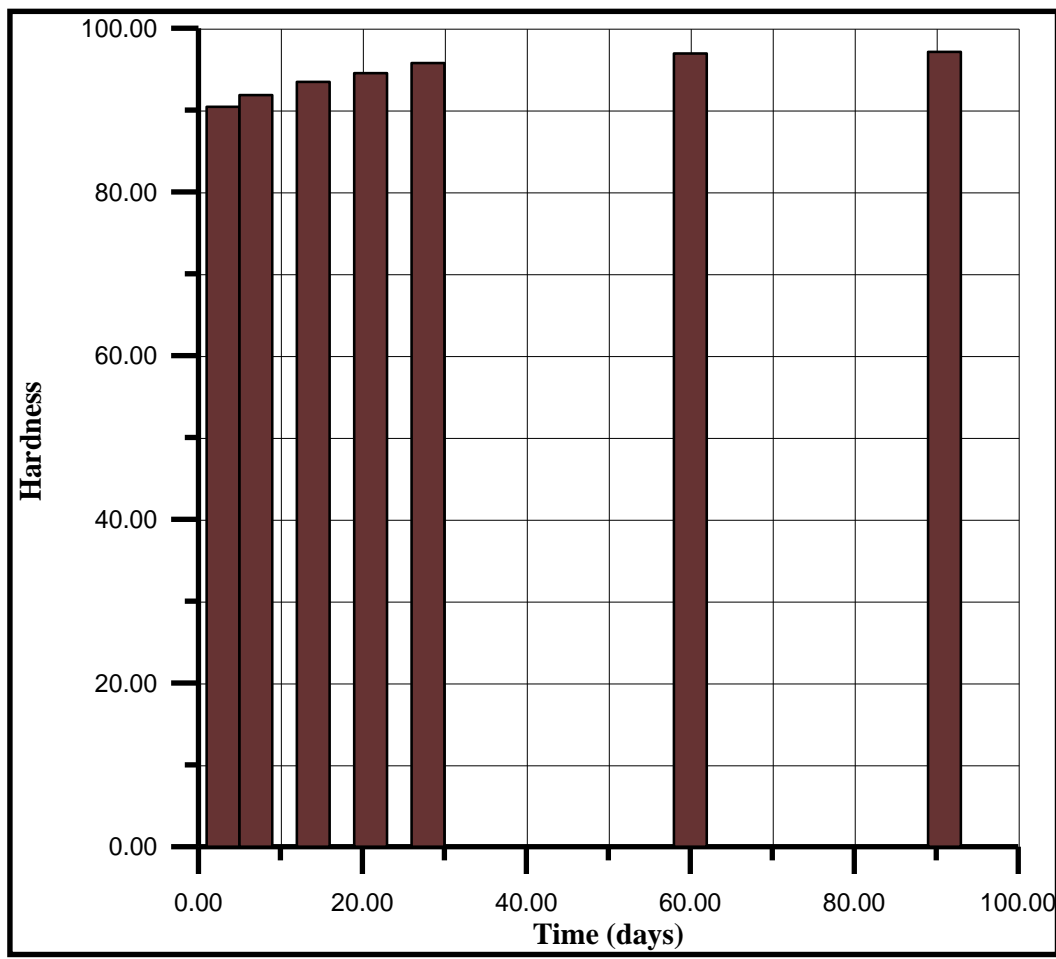

Fig.26: Surface hardness for (2\%) nano- $\mathrm{ZrO}_{2}$ (Colloidal)

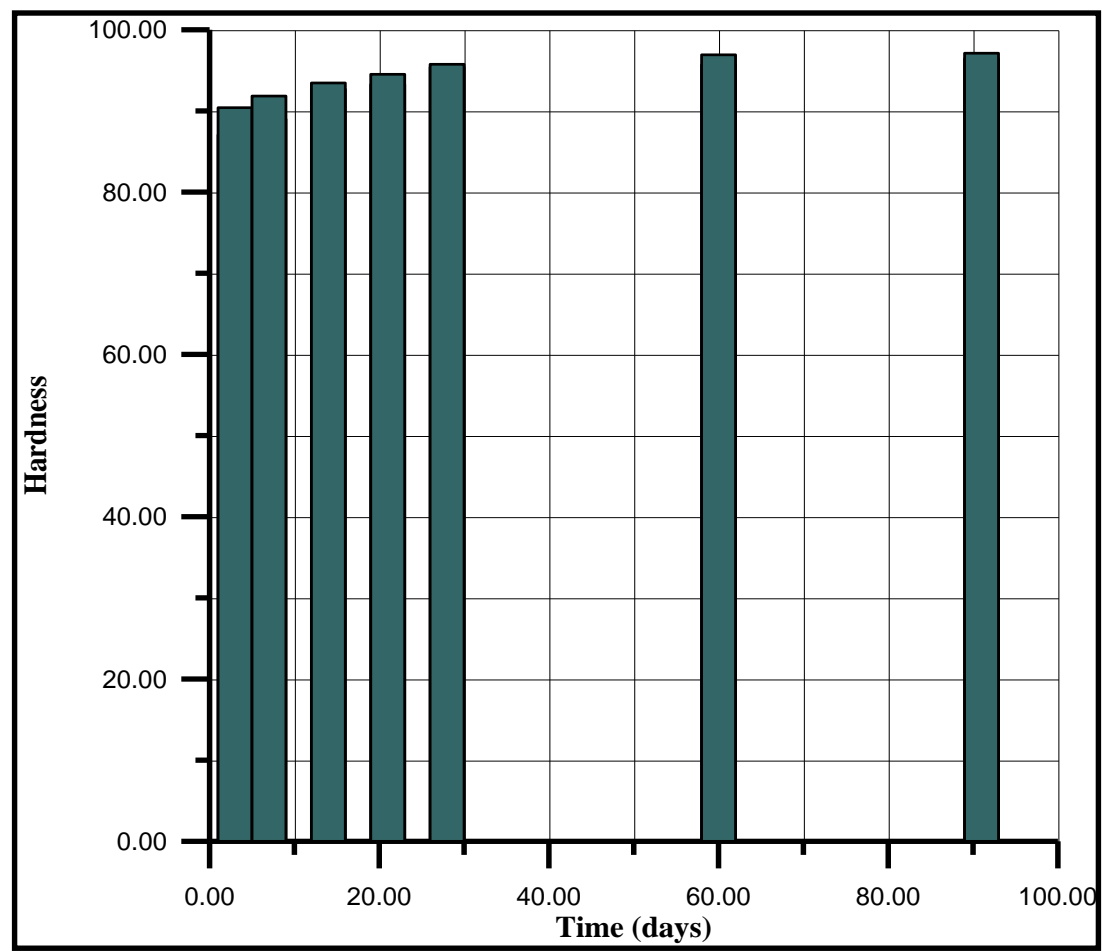

Fig.27: Surface hardness for $(2 \%)$ nano $\mathrm{ZrO}_{2}$ (dry) 


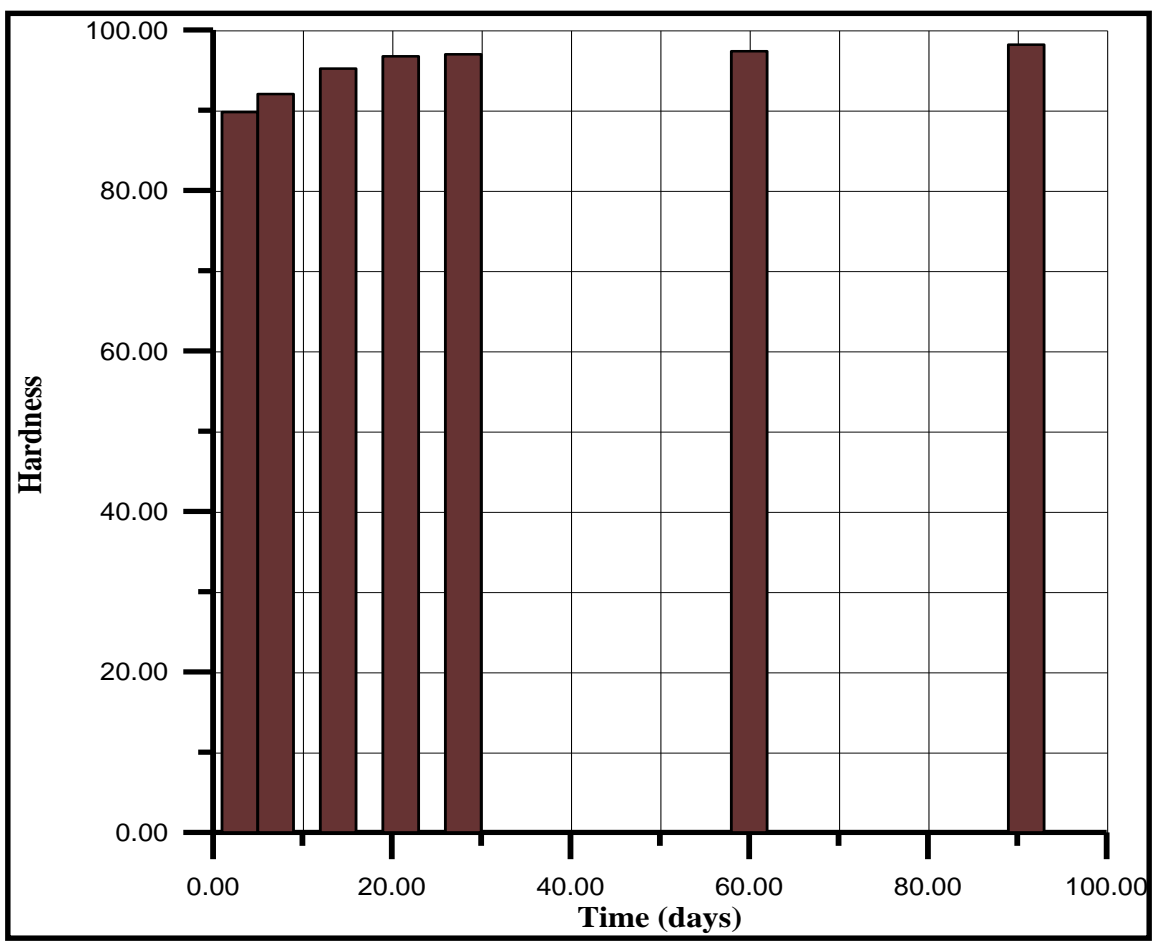

Fig.28: Surface hardness for (3\%) nano- $\mathrm{ZrO}_{2}$ (Colloidal)

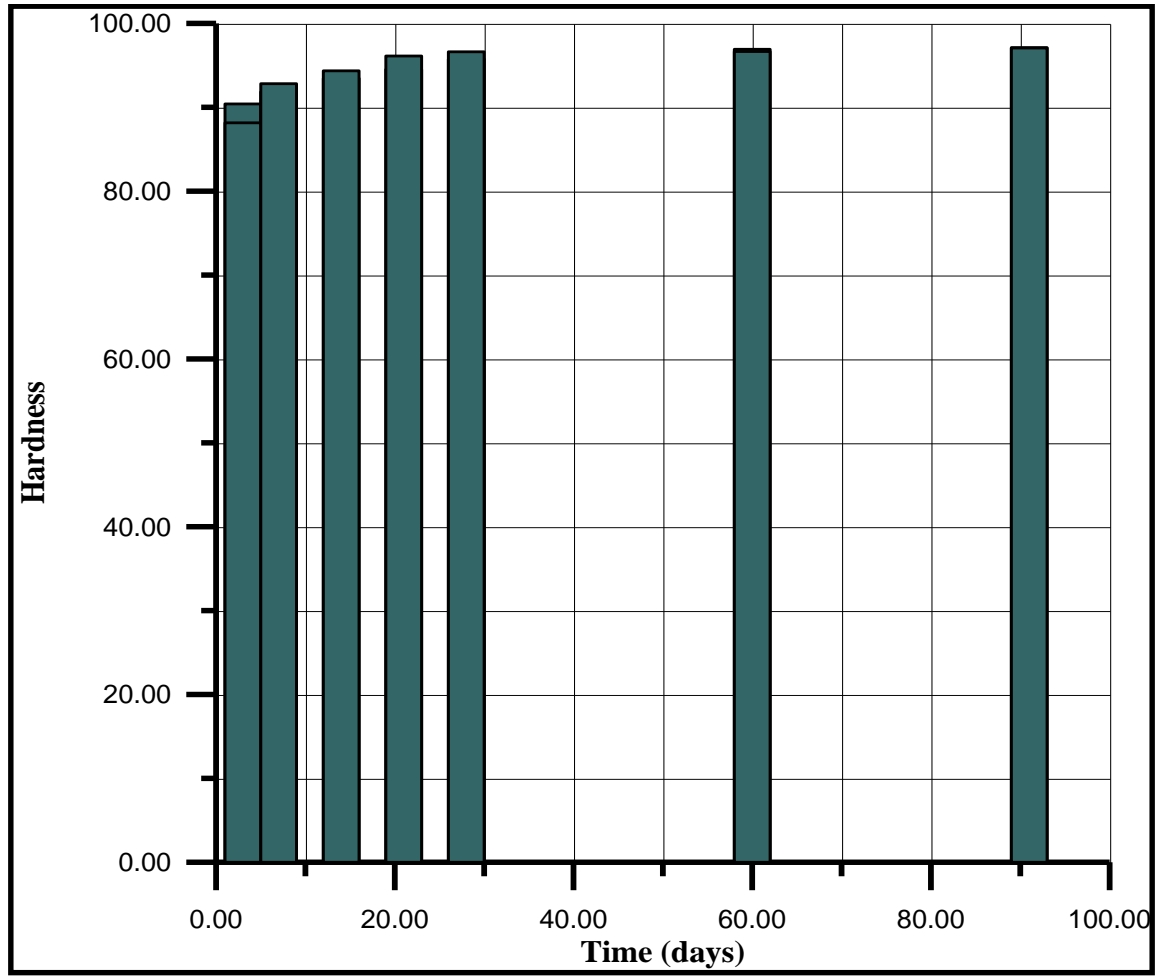

Fig.29: Surface hardness for (3\%) nano- $\mathrm{ZrO}_{2}$ (dry) 


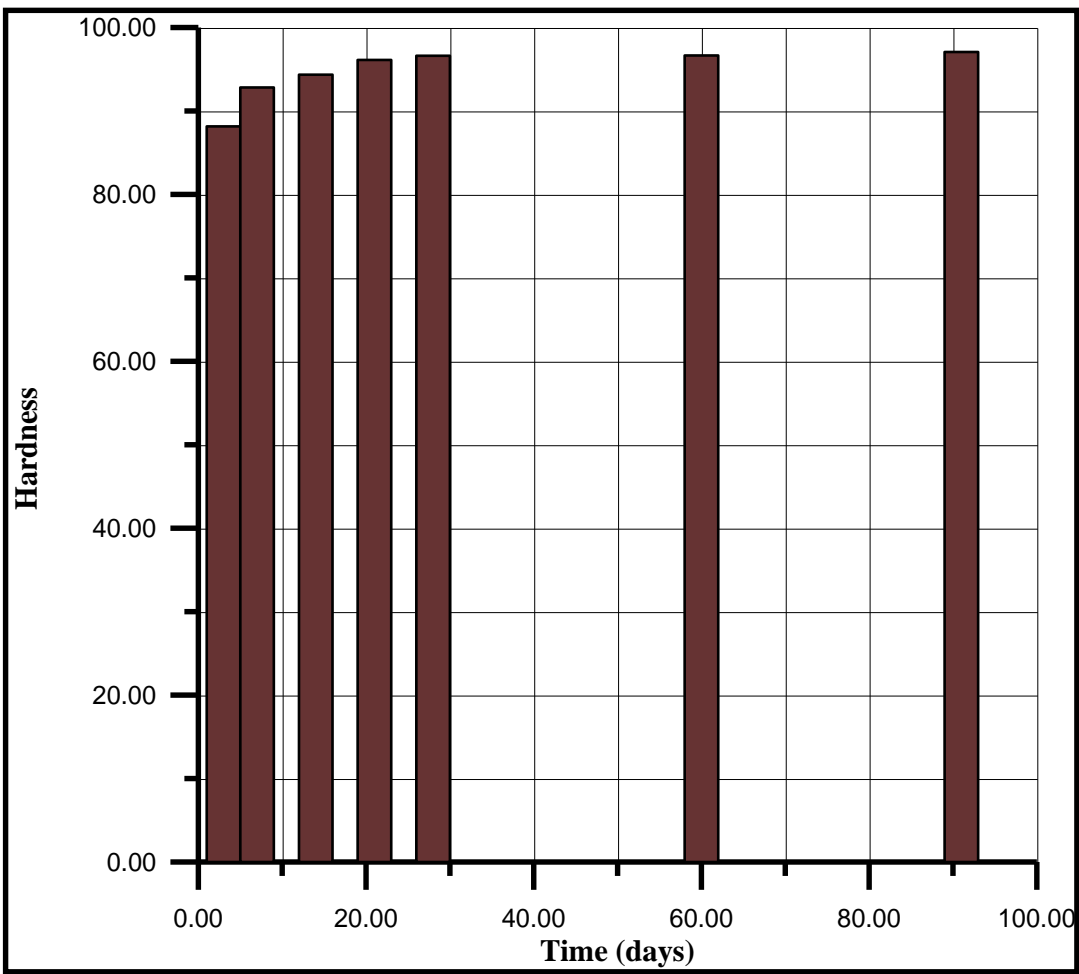

Fig.30: Surface hardness for (4\%) nano- $\mathrm{ZrO}_{2}$ (Colloidal)

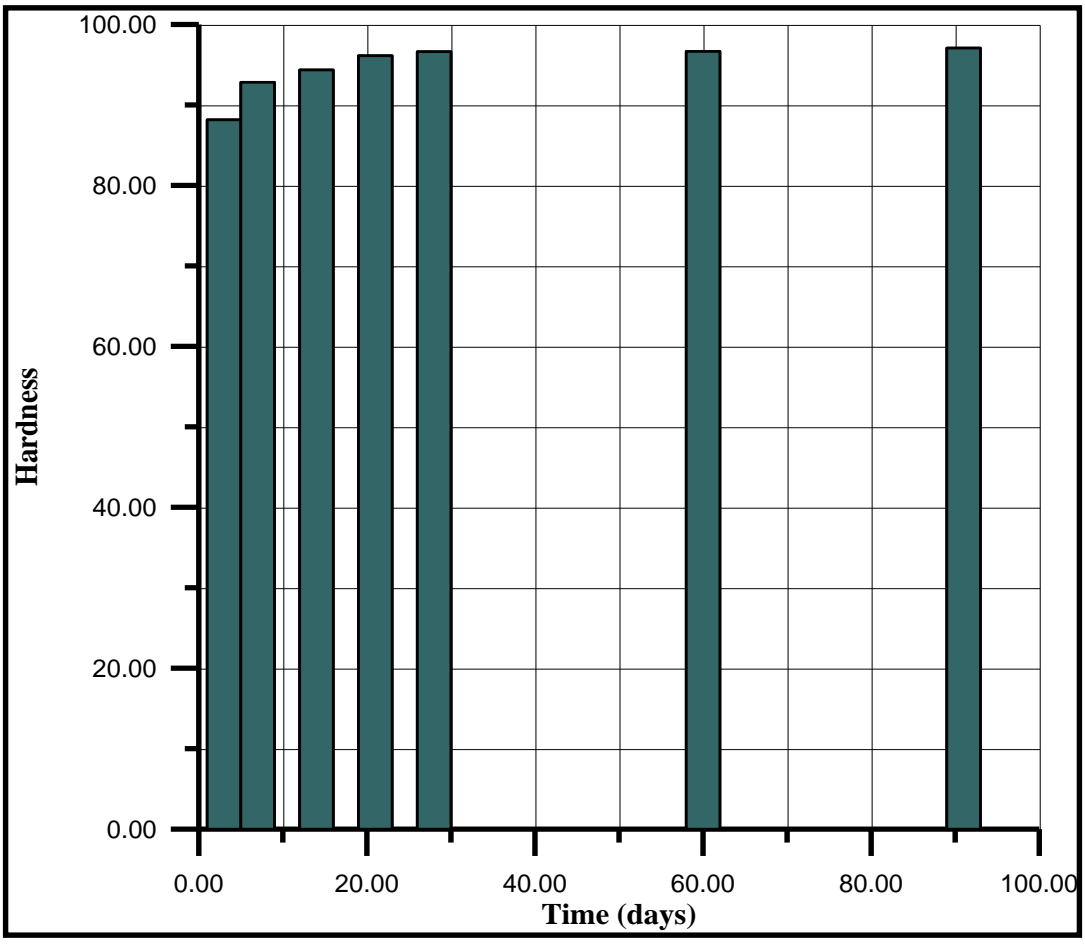

Fig.31: Surface hardness for $(4 \%)$ nano- $\mathrm{ZrO}_{2}$ (dry)

However, when the particles of nano Zirconia cannot be in good dispersion, when nano particles content are increases more than the critical content, the agglomeration of nano particles will create weakly zones area. Therefore the pores and The homogeneous structure during hydrating process can't be created and also the strength becomes low. 


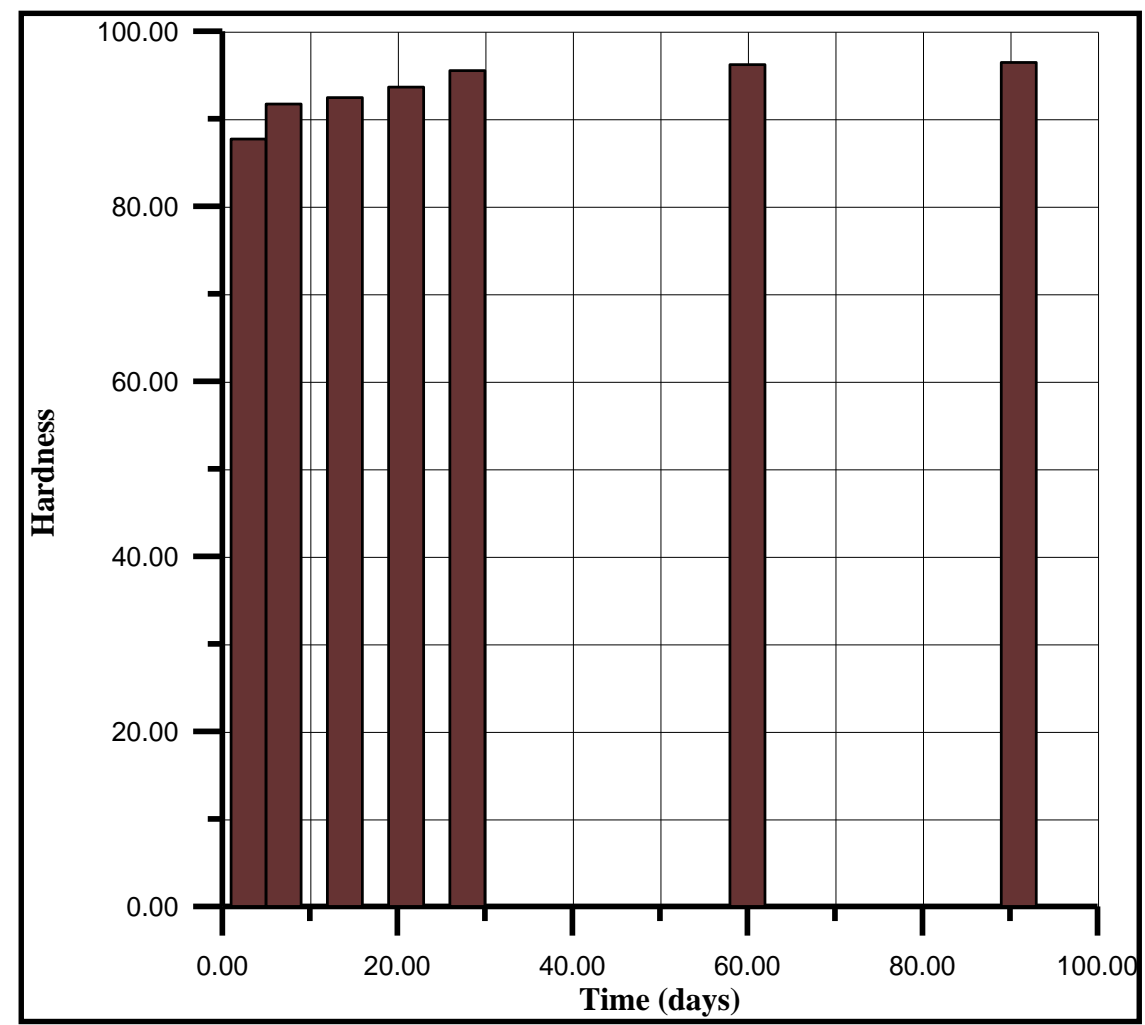

Fig.32: Surface hardness for $(5 \%)$ nano- $\mathrm{ZrO}_{2}$ (Colloidal)

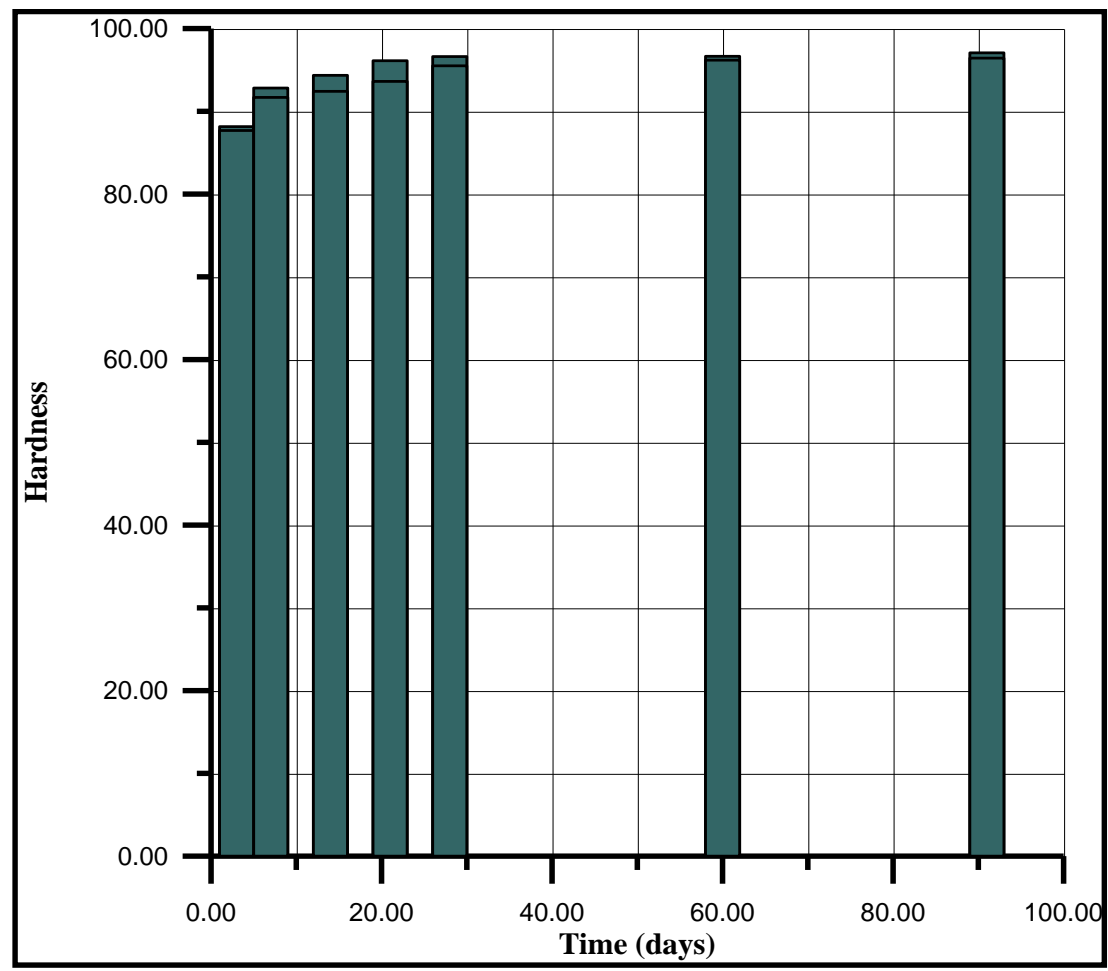

Fig.33: Surface hardness for $(5 \%)$ nano- $\mathrm{ZrO}_{2}$ (dry) 


\section{E-Conclusions:}

Based on the mechanical properties obtained by the tests on a reference cement mortar and nano-replacement mixes containing two types of nano- $\mathrm{ZrO}_{2}$ (dry and colloidal). In general, the present study showed that there is an improvement in the mechanical properties of nano cement mortar as developed in the present work which was experimentally investigated. This can be attributed to many factors, like mixing ratio as well as the type of the nanomaterials used. The following conclusions can be drawn according to the results from the experimental work, following points can be concluded:

1.The mechanisms of dispersion method of nano-particles in colloidal state give better dispersion than dry

State, this is contributed to give well homogenize distribution of nano-particles and preclude the agglomeration will occur.

2.The Nano- $\mathrm{ZrO}_{2}$ additives to the cement mortar as replacement by weight of cement can be effect as filler in order to strengthen the micro structure of cement mortar also consumed the amount and size of $\mathrm{Ca}(\mathrm{OH})_{2}$ and the voids of $(\mathrm{C}-\mathrm{S}-\mathrm{H})$ to be filled then the structure of hydrated of cement mortar becomes more dense .

3. At all curing ages, Compressive strength of mortar cubes cast contain nano- $\mathrm{ZrO}_{2}$ (Colloidal) was higher than containing the same amount of nano- $\mathrm{ZrO}_{2}$ (dry).

4.The improvement in compressive strength was $42 \%$ above reference mortar at 91 days; this compressive strength enhancement was produced at $2 \%$ nano- $\mathrm{ZrO}_{2}$ (Colloidal) replacement.

5.The development of compressive strength was $14 \%$ at 91 days above reference mortar; this enhancement in compressive strength was achieved at $2 \%$ nano- $\mathrm{ZrO}_{2}$ (dry) replacement.

6. Nano-particles improve compressive, flexural strength, surface hardness of all specimens containing both nano materials (nano- $\mathrm{ZrO}_{2}$ (Colloidal) and nano- $\mathrm{ZrO}_{2}$ (dry)).

7. As the content of $\mathrm{ZrO}_{2}$ nano-particles is increased up to $2 \mathrm{wt} \%$, the compressive strength, surface hardness and flexural strength of cement mortar specimens is increased. This is due to more formation of hydrated products in presence of $\mathrm{ZrO}_{2}$ nano-particles

\section{REFRENCES}

1. Sanchez F. and Sobolev K.," Nano Technology in concrete "- a review, Constr. Build Mater., 24, 2060-71 (2010).

2. Bjornstrom J., Martinelli A., Matic A., Borjesson L. and I. Panas, "Accelerating effects of colloidal nano-silica for beneficial calcium-silicate-hydrate formation in cement" Chemical Physics Letters, 392, 242-248 (2004).

3. Hanus, M.J.; and Harris, A.T. "Nanotechnology innovations for the construction industry". Progress in Materials Science, 58, 1056-1102, (2013).

4. Pacheco-Torgal, F.; and Jalali, S. "Nanotechnology: Advantages and drawbacks in the field of construction and building materials", Construction and Building Materials, 25, 582-590, (2011)

5. Singh, L.P.; Karade, S.R.; Bhattacharyya, S.K.; Yousuf, M.M.; and Ahalawat, S. "Beneficial role of nanosilica in cement based materials "- A review. Construction and Building Materials, 47, 1069-1077, (2013).

6. Lebental, B.; Chainais, P.; Chenevier, P.; Chevalier, N.; Delevoye, E.; and Fabbri, J.M. "Aligned carbon nanotube based ultrasonic microtransducers for durability monitoring in civil engineering" Nanotechnology, 22, 395501, (2011).

7. Broekhuizen, P.; Broekhuizen, F.; Cornlissen, R.; and Reijnders, L. "Use of nanomaterials in the European construction industry and some occupational health aspects thereof" Journal of Nanoparticle Research, 13 447-62. (2011)

8. Nazari, A.; and Riahi, S. "TiO ${ }_{2}$ nanoparticle effects on physical, thermal and mechanical properties of selfcompacting concrete with ground granulated blast furnace slag as binder". Energy and Buildings, 43(4), 995-1002. (2011).

9. Nazari, A.; and Riahi, S. "Improvement compressive strength of concrete in different curing media by $\mathrm{Al}_{2} \mathrm{O}_{3}$ nanoparticles". Material Science and Engineering: $A$, 528(3), 1183-1191. (2011).

10. Hekari, A.H.; and Razzaghi, M.S. "Influence of nano particles on durability and mechanical properties of high performance concrete" Procedia Engineering, 14, 303641, (2011).

11. Li, H.; Xiao, H.G.; and Ou, J. "A study on mechanical and pressure-sensitive properties of cement mortar with nanophase materials". Cement and Concrete Research, 34, 435-438, (2004).

12. Senff, L.; Hotza, D.; Lucas, S.; Ferreira, V.M.; and Labrincha, J.A. "Effect of nano-SiO ${ }_{2}$ and nano-TiO ${ }_{2}$ addition on the rheological behavior and the hardened properties of cement mortars" Material Science and Engineering: A, 532, 354-356, (2012).

13. Kuo, W.Y.; Huang, J.S.; and Yu, B.Y. "Evaluation of strengthening through stress relaxation testing of organomodified montmorillonite reinforced cement mortars" Construction and Building Materials, 25, 2771-2776, (2011). 
14. Xiao, H.; Gang, H.; Jie, Y., and Jinping, O. "Microstructure of cement mortar with nano-particles" Composites: Part B, 35, 185-189, (2004).

15. Meral, O.; and Remzi, S. "Pore structure analysis of hardened cement mortars containing silica fume and different nano-powders" Construction and Building Materials, 53, 658-664, (2014).

16. Senff, L.; Hotza; D., Lucas, S.; Ferreira, V.M.; and Labrincha, J.A. "Effect of nano-SiO2 and nano-TiO addition on the rheological behavior and the hardened properties of cement mortars. Influence of nano particles on durability and mechanical properties of high performance concrete" 532, 354-361, (2012).

17. Chen, L.; and Lin, D.F. "Applications of sewage sludge ash and nano-SiO $\mathrm{O}_{2}$ to manufacture tile and construction material", Construction and Building Materials, 23, 331220, (2009).

18. Al-Rifaie, W.N.; Ahmed, W.K.; and Mohanad, M.O. "Performance of Ferrocement Using NSCSC Mortar" NURER 2012-Proceedings of the 3rd International Conference on Nuclear \& Renewable Energy Resources. İstanbul, Turkey. (2012).

19. Zhang, M.H.; and Li, H. "Pore structure and chloride permeability of concrete containing nano-particles for pavement" Construction and Building Materials, 25, 60816,(2011).

20. Shekari, A.H.; and Razzaghi, M.S. "Influence of nano particles on durability and mechanical properties of high performance concrete" Procedia Engineering, 14, 30363041, (2011).

21. Oscar, M.; Germán, S.; and Jorge, T. "Effect of the reagglomeration process of multi-walled carbon nanotubes dispersions on the early activity of nanosilica in cement composites" Construction and Building Materials, 54, 550-557, (2014).

22. Shengwei, S.; Xun, Y.; Baoguo, H.; and Jinping, O. "In situ growth of carbon nanotubes/carbon nanofibers on cement/mineral admixture particles" A review. Construction and Building Materials, 49, 835-840, (2013).

23. Jo, B.W.; Kim C.H.; and Lim, J.H. "Characteristics of cement mortar with nano-SiO2 particles" ACI Materials Journal, 104, 404-407, (2007).

24. ASTM C 348 - 02"Standard Test Method for Flexural Strength of Hydraulic-Cement Mortars" Designation: C $348-02,(2010)$.

25. ASTM D2240 "Standard test method for rubber property durometer hardness "book of standard, vol.9, no.1, (2010). 